\title{
Impact of biomass burning emission on total peroxy nitrates: fire plume identification during the BORTAS campaign
}

\author{
Eleonora Aruffo ${ }^{1,2}$, Fabio Biancofiore ${ }^{1}$, Piero Di Carlo ${ }^{1,2, a}$, Marcella Busilacchio ${ }^{1}$, Marco Verdecchia ${ }^{1,2}$, \\ Barbara Tomassetti $^{1,2}$, Cesare Dari-Salisburgo ${ }^{1}$, Franco Giammaria ${ }^{1}$, Stephane Bauguitte ${ }^{3}$, James Lee ${ }^{4}$, \\ Sarah Moller ${ }^{4}$, James Hopkins ${ }^{4}$, Shalini Punjabi ${ }^{4}$, Stephen J. Andrews ${ }^{4}$, Alistair C. Lewis ${ }^{4}$, Paul I. Palmer ${ }^{5}$, \\ Edward Hyer $^{6}$, Michael Le Breton ${ }^{7}$, and Carl Percival ${ }^{7}$ \\ ${ }^{1}$ Center of Excellence CETEMPS, Universita' dell'Aquila, Via Vetoio, Coppito, L'Aquila, Italy \\ ${ }^{2}$ Department of Physical and Chemical Sciences, University of L'Aquila, Coppito L'Aquila, Italy \\ ${ }^{3}$ Facility for Airborne Atmospheric Measurements, Bedfordshire, UK \\ ${ }^{4}$ Department of Chemistry, University of York, York, UK \\ ${ }^{5}$ School of GeoSciences, University of Edinburgh, Edinburgh, UK \\ ${ }^{6}$ Marine Meteorology Division, Naval Research Laboratory, Monterey, California, USA \\ ${ }^{7}$ The Centre for Atmospheric Science, School of Earth, Atmospheric and Environmental Science, \\ University of Manchester, Manchester, UK \\ anow at: Department of Psychological, Health and Territorial Sciences, University "G. d'Annunzio", \\ Chieti-Pescara, Italy
}

Correspondence to: Eleonora Aruffo (eleonora.aruffo@aquila.infn.it)

Received: 11 February 2016 - Published in Atmos. Meas. Tech. Discuss.: 21 March 2016

Revised: 29 September 2016 - Accepted: 11 October 2016 - Published: 23 November 2016

\begin{abstract}
Total peroxy nitrate ( $\left.\sum \mathrm{PN}\right)$ concentrations have been measured using a thermal dissociation laser-induced fluorescence (TD-LIF) instrument during the BORTAS campaign, which focused on the impact of boreal biomass burning (BB) emissions on air quality in the Northern Hemisphere. The strong correlation observed between the $\sum$ PN concentrations and those of carbon monoxide (CO), a wellknown pyrogenic tracer, suggests the possible use of the $\sum \mathrm{PN}$ concentrations as marker of the BB plumes. Two methods for the identification of BB plumes have been applied: (1) $\sum \mathrm{PN}$ concentrations higher than 6 times the standard deviation above the background and (2) $\sum$ PN concentrations higher than the 99th percentile of the $\sum$ PNs measured during a background flight (B625); then we compared the percentage of BB plume selected using these methods with the percentage evaluated, applying the approaches usually used in literature. Moreover, adding the pressure threshold $(\sim 750 \mathrm{hPa})$ as ancillary parameter to $\sum \mathrm{PNs}$, hydrogen cyanide $(\mathrm{HCN})$ and $\mathrm{CO}$, the $\mathrm{BB}$ plume identification is improved. A recurrent artificial neural network (ANN) model was adapted to simulate the concentrations of $\sum$ PNs and
\end{abstract}

$\mathrm{HCN}$, including nitrogen oxide $(\mathrm{NO})$, acetonitrile $\left(\mathrm{CH}_{3} \mathrm{CN}\right)$, $\mathrm{CO}$, ozone $\left(\mathrm{O}_{3}\right)$ and atmospheric pressure as input parameters, to verify the specific role of these input data to better identify BB plumes.

\section{Introduction}

Biomass burning (BB) events are an important source of many trace gases and particles in the atmosphere (Crutzen et al., 1979; Crutzen and Andreae, 1990; Goode et al., 2000; Andreae and Merlet, 2001). The signature of BB emission in a plume detected far away from the fire is usually the increase of the atmospheric concentration of pyrogenic species including carbon dioxide $\left(\mathrm{CO}_{2}\right)$, $\mathrm{CO}$, methane $\left(\mathrm{CH}_{4}\right)$ and a series of volatile organic compounds (VOCs), accompanied by elevated concentrations of peroxyacyl nitrate (PAN) (e.g. Goode et al., 2000; Cofer et al., 1998; Bertschi et al., 2004; Dibb et al., 2003; Lewis et al., 2007; Tereszchuk et al., 2011).

In recent years, several studies have focused on boreal forest fires to quantify the influence of boreal fire emissions 
on the Earth-atmosphere system and subsequent impact on the climate. Boreal forest fires (http://www.borealforest.org) affect mainly Siberia, Canada and Alaska and occur generally from May to October (Lavoué et al., 2000). In the past 3 decades occurrence of boreal forest fires and areas burned over Canada have both increased (Gillett et al., 2004; Rinsland et al., 2007; Marlon et al., 2008). The impact of boreal $\mathrm{BB}$ on atmospheric chemistry is triggered by the large emissions of $\mathrm{CO}, \mathrm{NO}_{x}\left(\mathrm{NO}+\mathrm{NO}_{2}\right)$, nonmethane hydrocarbons (NMHCs) and other $\mathrm{NO}_{y}$ species (Alvarado et al., 2010; Parrington et al., 2013). $\mathrm{NO}_{y}=\mathrm{NO}_{x}+$ $\sum \mathrm{RONO}_{2}+\sum \mathrm{RO}_{2} \mathrm{NO}_{2}+\mathrm{HNO}_{3}+\mathrm{HONO}+2 \mathrm{~N}_{2} \mathrm{O}_{5}+\mathrm{NO}_{3}^{-}$, where $\sum \mathrm{RONO}_{2}$ are total alkyl nitrates (known also as $\sum \mathrm{ANs}$ ), $\sum \mathrm{RO}_{2} \mathrm{NO}_{2}$ are total peroxy nitrates (known also as $\sum \mathrm{PNs}$ ), $\mathrm{HNO}_{3}$ is nitric acid, $\mathrm{HONO}$ is nitrous acid, $\mathrm{N}_{2} \mathrm{O}_{5}$ is dinitrogen pentoxide and $\mathrm{NO}_{3}^{-}$is nitrate. These species can influence the formation of $\mathrm{O}_{3}$ in the Arctic and at the midlatitudes: the role of boreal $\mathrm{BB}$ emissions on the $\mathrm{O}_{3}$ concentration has been studied by several authors, showing situations where $\mathrm{O}_{3}$ concentrations increased and others where it was unaffected (e.g. Wofsy et al., 1992; Jacob et al., 1992; Mauzerall et al., 1996; Wotawa and Trainer, 2000; Val Martin et al., 2006; Real et al., 2007; Leung et al., 2007, Jaffe and Wigder, 2012; Parrington et al., 2012, 2013). The formation of $\mathrm{NO}_{x}$ oxidation products ( $\sum \mathrm{ANs}, \sum \mathrm{PNs}$ and $\left.\mathrm{HNO}_{3}\right)$ plays a very important role in controlling the ozone budget as they inhibit local $\mathrm{O}_{3}$ formation (Leung et al., 2007). Many investigations demonstrated the central role played by PAN, one of the most common PNs, in BB plume chemistry and, specifically, in the $\mathrm{NO}_{x}$ oxidation processes (Jacob et al., 1992; Hudman et al., 2007). Alvarado et al. (2010) demonstrated the rapid PAN formation occurring within 1-2 $\mathrm{h}$ after the emissions by a BB plume: $40 \%$ of the $\mathrm{NO}_{x}$ initially emitted by the fires is rapidly converted into PAN and $20 \%$ into $\mathrm{NO}_{3}^{-}$(particles phase). In aged plumes, PAN can represent up to $67 \%$ of the $\mathrm{NO}_{y}$ budget (Alvarado et al., 2010).

Analysis of the chemistry of BB emissions starts with identifying a BB plume; however, previous studies have used multiple different approaches for the identification and classification of $\mathrm{BB}$ plumes. Many studies have recognised $\mathrm{CO}$ as a pyrogenic species (Crutzen et al., 1979; Andreae and Merlet, 2001; Lewis et al., 2013), but other chemical species, such as $\mathrm{HCN}$ and $\mathrm{CH}_{3} \mathrm{CN}$, have also been employed to identify a BB plume. In the assembly of the BORTAS data analysis, different procedures have been applied. Palmer et al. (2013) identified a threshold for each of these species that would separate air masses produced during boreal BB from background air masses; they defined a $\mathrm{BB}$ plume when the $\mathrm{CO}, \mathrm{HCN}$ and $\mathrm{CH}_{3} \mathrm{CN}$ volume mixing ratios are higher than $148 \mathrm{ppb}, 122$ and $150 \mathrm{ppt}$, respectively. These thresholds correspond to the 99th percentile $(\sim$ mean $\pm 3 \sigma)$ of the data for the species measured during flight B625, in which there was not a significant correlation between the $\mathrm{CO}$ and the $\mathrm{CH}_{3} \mathrm{CN}$. In the context of the BORTAS campaign, Lewis et al. (2013) classified the air masses in three groups: (1) back- ground if $\mathrm{CO}<200 \mathrm{ppb}$; (2) $\mathrm{BB}$ plumes if the $\mathrm{CO}>200 \mathrm{ppb}$ with the presence of pyrogenic species such as furan and furfural; (3) anthropogenic plumes if $\mathrm{CO}>200 \mathrm{ppb}$ with the absence of furan and furfural. Le Breton et al. (2013) observed a strong correlation between the $\mathrm{HCN}, \mathrm{CO}$ and $\mathrm{CH}_{3} \mathrm{CN}$, indicating the utilisation of $\mathrm{HCN}$ as a BB marker. They identified a BB plume using a standard deviation $(\sigma)$ method applied to the $1 \mathrm{~Hz} \mathrm{HCN}$ measurements: when the $\mathrm{HCN}$ concentrations were $6 \sigma$ above the background for the flights in analysis, they flagged the air mass as a BB plume. The background has been selected as the measurements done at low HCN concentrations outside its evident enhancement in the plume. The $6 \sigma$ threshold was chosen since it produces the highest $R^{2}$ values for the correlation between the HCN and the CO. For other experiments different methods for the BB plumes identification have been suggested. (1) Holzinger et al. (2005) used a method similar to that used by Le Breton et al. (2013); their results highlighted a good correlation between $\mathrm{CH}_{3} \mathrm{CN}$ and $\mathrm{CO}$ and they identified $\mathrm{BB}$ plumes by significant peaks in the $\mathrm{CH}_{3} \mathrm{CN}$ volume mixing ratio (using a threshold of $3 \sigma$ above the background level). (2) Vay et al. (2011) identified a plume when $\mathrm{CO}>160 \mathrm{ppb}$ (the median observed $\mathrm{CO}$ concentration at the surface), $\mathrm{CH}_{3} \mathrm{CN}>225 \mathrm{ppt}$ (threshold characterized by an evident enhancement in $\mathrm{CH}_{3} \mathrm{CN}$ mixing ratios) or $\mathrm{HCN}>500 \mathrm{ppt}$ (when the $\mathrm{CH}_{3} \mathrm{CN}$ was not available). (3) Hornbrook et al. (2011) defined a plume by elevated fire tracers above the local background using thresholds of $\mathrm{CH}_{3} \mathrm{CN}>200 \mathrm{ppt}, \mathrm{HCN}>400 \mathrm{ppt}$ and $\mathrm{CO}>175 \mathrm{ppb}$. (4) Tereszchuk et al. (2011) selected as BB plumes air masses when $\mathrm{HCN}>350 \mathrm{ppt}$, assuming that background concentrations of $\mathrm{HCN}$ in the free troposphere range between 225 and 250 ppt. Finally, (5) Alvarado et al. (2010) observed the enhancement of $\mathrm{CO}$ correlated with an enhancement in $\mathrm{HCN}$ and $\mathrm{CH}_{3} \mathrm{CN}$; they identified a plume as having a $\mathrm{CO}$ concentration at least $20 \mathrm{ppb}$ above the background level.

An aircraft campaign was conducted in Nova Scotia (Canada) with the main purpose of evaluating the BB emissions impact on tropospheric photochemistry in the Northern Hemisphere. This work is part of the BORTAS project (quantifying the impact of BOReal forest fires on Tropospheric oxidants over the Atlantic using Aircraft and Satellites). This project included a field campaign using a research aircraft (the FAAM BAe-146) conducted in July and August 2011 during the boreal forest fire season in Canada. Further details about this project can be found in Palmer et al. (2013) and at http://www.geos.ed.ac.uk/research/eochem/bortas/.

In our analysis of the BORTAS aircraft measurement data, we found a good correlation between the $\sum \mathrm{PNs}$ and $\mathrm{CO}$, suggesting the potential of $\sum \mathrm{PNs}$ as pyrogenic tracer to discriminate the BB plumes. Therefore, in this work we propose two different methods to use the $\sum$ PNs as BB tracer: a statistical approach using the $6 \sigma$ threshold and the 99th percentile of the $\sum$ PNs calculated for the B625 flight. We evaluated all of the methods described above with our dataset to compare the results of different methods to identify BB 
plumes. We show also that, in some cases, the introduction of meteorological parameters, which take into account the air masses vertical position in the atmosphere, discriminates better the origin of the air masses and, then, helps to select a BB plume more precisely. Finally, in order to refine the method we adapted an artificial neural network (ANN) model and we used it to simulate the $\sum \mathrm{PNs}$ and the $\mathrm{HCN}$ in two different procedures to $\mathrm{BB}$ plume identification: (1) using as inputs $\mathrm{CO}, \mathrm{NO}, \mathrm{CH}_{3} \mathrm{CN}$ and $\mathrm{O}_{3}$; (2) adding the pressure to the inputs as proxy of the vertical position of air masses.

\section{Experimental}

\subsection{Thermal dissociation laser-induced fluorescence (TD-LIF) measurements: $\mathrm{NO}_{2}, \sum \mathrm{PNs}, \sum \mathrm{ANs}$}

A detailed description of the BORTAS experiment can be found in Palmer et al. (2013), along with a description of the FAAM BAe-146 instrumental payload. During BORTAS campaign (Canada, summer 2011), observations of $\mathrm{NO}_{2}$, total $\sum$ PNs and $\sum$ ANs, on board the British FAAM BAe 146 research aircraft were carried out using the TD-LIF instrument developed at the University of L'Aquila (Italy) (DariSalisburgo et al., 2009; Di Carlo et al., 2013). Briefly, this technique uses laser-induced fluorescence to measure directly $\mathrm{NO}_{2}$ molecules, whereas $\Sigma$ PNs, $\Sigma$ ANs and $\mathrm{HNO}_{3}$ are thermally dissociated into $\mathrm{NO}_{2}$, heating the air sample at 200,400 and $550{ }^{\circ} \mathrm{C}$, respectively (Day et al., 2002; Di Carlo et al., 2013). The configuration and the performances of the TD-LIF employed during the BORTAS campaign are unchanged with respect to those described in Di Carlo et al. (2013), and more information can be found in that paper.

\subsection{Ancillary measurements: $\mathrm{O}_{3}, \mathrm{CO}$, VOCs}

Table 1 reports a number of the compounds measured onboard the BAe-146 aircraft during the BORTAS campaign, specifically those used in this analysis. The instrument used to measure $\mathrm{O}_{3}$ was a commercial UV absorption system Model 49C (Thermo Environmental Corp.) (Wilson and Birks, 2006). CO was measured using the vacuum ultraviolet (VUV) resonance fluorescence technique. This type of $\mathrm{CO}$ instrument was applied to aircraft measurement by Gerbig et al. (1999). NO was measured using a single-channel chemiluminescence instrument manufactured by Air Quality Design, Inc. (Colorado, USA, http://www.airqualitydesign. $\mathrm{com} /$ ) (Lee et al., 2009; Reidmiller et al., 2010). Concentrations of VOCs ranging from $\mathrm{C} 5$ to $\mathrm{C} 12$ were measured by an automatic gas chromatograph system equipped with a mass spectrometer (GC-MS; Palmer et al., 2013). C2-C7 hydrocarbons and $\mathrm{C} 2-\mathrm{C} 5$ oxygenated volatile organic compounds (OVOCs), including alcohols, aldehydes, ketones and ethers, were obtained by the University of York (UK) using whole air sampling (WAS) coupled to an automatic gas chromatograph system equipped with a mass spectrometer

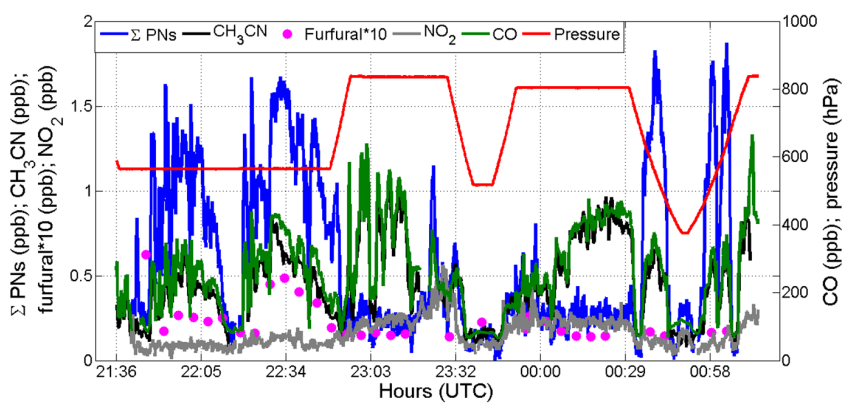

Figure 1. Time series of $\sum \mathrm{PNs}, \mathrm{CH}_{3} \mathrm{CN}$, furfural, $\mathrm{CO}, \mathrm{NO}_{2}$ and pressure during flight B623, shown as example.

and a flame ionisation detector (GC-MS/FID) (Hopkins et al., 2003). Measurements of a suite of volatile organic compounds (such as $\mathrm{CH}_{3} \mathrm{CN}$, isoprene $\left(\mathrm{C}_{5} \mathrm{H}_{8}\right)$ and methyl vinyl ketone plus methacrolein, MVK + MACR) were made by proton transfer reaction mass spectrometry (PTR-MS) (Murphy et al., 2010). Finally, a chemical ionisation mass spectrometer (CIMS) was used for measuring $\mathrm{HCN}$ from biomass burning events (Le Breton et al., 2013).

\section{Plume identification}

Figure 1 shows the time series of the species investigated in this paper ( $\sum \mathrm{PNs}, \mathrm{CH}_{3} \mathrm{CN}, \mathrm{HCN}, \mathrm{CO}, \mathrm{NO}_{2}$ and furfural) for one of the flights analysed (B623), illustrated as an example. The $\sum \mathrm{PN}$ trends show exactly the same structures observed on $\mathrm{CO}$ and $\mathrm{CH}_{3} \mathrm{CN}$, with the exception of two plumes (in the temporal intervals of $\sim 23.00-23.30$ UTC and $\sim 00.00$ 00.30 UTC) that are extensively analysed in the next sections. Moreover, the furfural shows a similar trend for the first part of the flight; since $\mathrm{CO}, \mathrm{CH}_{3} \mathrm{CN}$ and $\mathrm{HCN}$ are a known $\mathrm{BB}$ tracers and furfural is known to be emitted by $\mathrm{BB}$ (Lewis et al., 2013; Palmer et al., 2013; Le Breton et al., 2013), the significant correlation between the $\sum$ PNs and those species suggests that the $\sum$ PNs also originated at the same boreal BB source and that it can be used as additional chemical species for the identification of the BB plumes.

As described in the introduction, recently different compounds $\left(\mathrm{CO}, \mathrm{HCN}\right.$ or $\left.\mathrm{CH}_{3} \mathrm{CN}\right)$ and different concentrations thresholds have been used as tracers to establish whether the air mass monitored is affected by forest fire emissions or not. These methods are summarised in Table 2 .

In our analysis we tested the use of the concentration profiles of $\sum$ PNs as possible identifier of BB plumes. We applied two different methods: (1) evaluating the 99th percentile of the $\sum \mathrm{PN}$ concentrations measured during the background flight B625 (as done by Palmer et al., 2013) and using this value as the threshold to distinguish air masses emitted by fires; (2) applying the statistical approach ( $\sigma$ method). In the first case, we calculated the 99th percentile of the $1 \mathrm{~s} \sum \mathrm{PN}$ data (averaged at $10 \mathrm{~s}$ ) sampled during the B625 
Table 1. List of FAAM BAe-146 instrumental payload and observed compounds used in the analysis in this paper. A description of the FAAM BAe-146 instrumental payload, with accuracy and detection limit, is reported in Table 2 of Palmer et al. (2013).

\begin{tabular}{|c|c|c|c|}
\hline Species & & Method & Reference \\
\hline $\mathrm{CO}$ & & VUV resonance/fluorescence & Gerbig et al. (1999) \\
\hline $\mathrm{O}_{3}$ & & UV absorption & Wilson and Birks (2006) \\
\hline $\begin{array}{l}\mathrm{NO}_{2}, \sum \mathrm{RO}_{2} \mathrm{NO}_{2}, \sum \mathrm{RONO}_{2}, \\
\mathrm{HNO}_{3}\end{array}$ & & TD-LIF & $\begin{array}{l}\text { Dari-Salisburgo et al. (2009); } \\
\text { Di Carlo et al. (2013) }\end{array}$ \\
\hline NO & & AQD chemiluminescence & $\begin{array}{l}\text { Lee et al. (2009); } \\
\text { Reidmiller et al. (2010) }\end{array}$ \\
\hline $\mathrm{C}_{5}-\mathrm{C}_{12}$ VOCs & & GC-MS & Palmer et al. (2013) \\
\hline $\begin{array}{l}\mathrm{C}_{2}-\mathrm{C}_{7} \mathrm{NMHCs} \text {, acetone } \\
\mathrm{CH}_{3} \mathrm{OH}\end{array}$ & & WAS-GC & Hopkins et al. (2003) \\
\hline $\mathrm{HCN}$ & & CIMS & Le Breton et al. (2013) \\
\hline $\begin{array}{l}\mathrm{CH}_{3} \mathrm{CN}, \quad \mathrm{C}_{3} \mathrm{H}_{6} \mathrm{O}, \\
\mathrm{MVK}+\mathrm{MACR}, \\
\mathrm{C}_{4} \mathrm{H}_{8} \mathrm{O}, \mathrm{C}_{6} \mathrm{H}_{6}, \mathrm{C}_{7} \mathrm{H}_{8}, \mathrm{C}_{10} \mathrm{H}_{16}\end{array}$ & $\mathrm{C}_{5} \mathrm{H}_{8}$ & PTR-MS & Murphy et al. (2010) \\
\hline
\end{tabular}

Table 2. Methods to identify BB plumes.

\begin{tabular}{ll}
\hline & Methods \\
\hline $\begin{array}{l}\text { Holzinger et al. (2005) } \\
\text { Alvarado et al. (2010) }\end{array}$ & $\begin{array}{l}\mathrm{CH}_{3} \mathrm{CN}>3 \sigma^{*} \\
\mathrm{CO} \text { increase of at least } 20 \mathrm{ppb} \text { with respect to the background and its corre- } \\
\text { lation with } \mathrm{HCN} \text { or } \mathrm{CH}_{3} \mathrm{CN}\end{array}$ \\
& $\mathrm{CO}>160 \mathrm{ppb}, \mathrm{HCN}>500 \mathrm{ppt}$ or $\mathrm{CH}_{3} \mathrm{CN}>225 \mathrm{ppt}$ \\
Vay et al. (2011) & $\mathrm{CO}>175 \mathrm{ppb}, \mathrm{HCN}>400 \mathrm{ppt}, \mathrm{CH}_{3} \mathrm{CN}>200 \mathrm{ppt}$ \\
Hornbrook et al. (2011) & $\mathrm{HCN}>350 \mathrm{ppt}$ \\
Tereszchuk et al. (2011) & $\mathrm{CO}>200 \mathrm{ppb}$ and presence of furan and furfural \\
Lewis et al. (2013) & $\mathrm{CO}>148 \mathrm{ppb}, \mathrm{HCN}>122 \mathrm{ppt}$ and $\mathrm{CH}_{3} \mathrm{CN}>150 \mathrm{ppt}$ \\
Palmer et al. (2013) & $\mathrm{HCN}>6 \sigma^{*}$ \\
Le Breton et al. (2013) & $\sum \mathrm{PNs}>6 \sigma^{*}$ or $\sum \mathrm{PNs}>418 \mathrm{ppt}$ \\
This work &
\end{tabular}

* $\sigma$ above the mean of the background concentrations.

and found a threshold of 418 ppt. In the second case, first we selected the parts of each flight identifiable as background as the mean of the concentrations measured before or after the $\sum \mathrm{PN}$ enhancement in the plumes and then we evaluated the mean and the standard deviation of the $\sum$ PNs corresponding to these data; after that, we identified as BB plumes the parts of each flight in which the difference between $\sum \mathrm{PN}$ concentrations and the background level were higher than 6 standard deviations of the background. This threshold has been evaluated by calculating the correlation coefficients between the $\sum$ PNs and the CO, varying the sigma threshold between $10 \sigma$ and $3 \sigma$ for each flight in which the $\sum$ PNs showed evident and clear plumes (such as B622 and B623): we found that the maximum $R$ occurred when we selected the BB plume using the $6 \sigma$ threshold. In Table 3 the correlation coefficients $R$ and the percentage of flight selected as BB plume (obtained for all the flights in analysis using both the methods just described) are summarised. Moreover, we indicated the percentage of flight identified as BB plume by applying all the methods listed in Table 2 to our dataset.
In order to make the analysis as accurate as possible, the double flights were separated and all the methods were applied in each part of the flights, taking into account of different Canadian regions and different hours of the day during which we were flying. The $\sum$ PN methods give, in most cases, results in agreement with each of the methods that use $\mathrm{CO}, \mathrm{HCN}$ and $\mathrm{CH}_{3} \mathrm{CN}$ (see Table 3) and allow us to discriminate three flights (B621a, B622 and B623) in which a significant percentage (higher than the $40 \%$ with $R$ ranging between 0.804 and 0.953 ) of the data has been collected, sampling air masses emitted by biomass burning. Moreover, these results are also in agreement with what is found by applying the approaches suggested in other studies. We found three flights (B621b, B626b and B628b) in which the majority of the methods show that a small percentage (less than $12 \%$ with $R$ ranging between 0.477 and 0.755 ) of data can be identified as BB plumes (see Table 3). In six flights (B619a, B619b, B620, B626a, B627 and B628a) the $\sum$ PN $6 \sigma$ method suggests, in agreement with the majority of the other techniques, a dominance of background air masses sampled; the 
Table 3. Correlation coefficient $(R)$ and percentage $(\%)$ of each flight of the BORTAS campaign selected as BB plume using both the $\sum$ PN methods ( $6 \sigma$ and 99 th percentile thresholds) and percentage $(\%)$ of BB plume evaluated for each BORTAS flight using the methods applied in other studies. In bold-italic we highlighted three flights with evidence of sampled significant BB plumes.

\begin{tabular}{|c|c|c|c|c|c|c|}
\hline \multirow[t]{3}{*}{ Flight } & \multicolumn{3}{|c|}{ This study ( $\sum \mathrm{PN}$ methods) } & \multicolumn{3}{|c|}{ Other studies } \\
\hline & $6 \sigma$ & \multicolumn{2}{|c|}{$\begin{array}{c}\sum \mathrm{PNs}>0.418 \mathrm{ppb} \\
\text { 99th percentile }\end{array}$} & & \multirow[b]{2}{*}{$\%$} & \multirow[b]{2}{*}{ Comments } \\
\hline & $R \quad \%$ & $R$ & $\%$ & & & \\
\hline B619a & 0 & -0.045 & 13.5 & Palmer et al. (2013) & 0 & Only CO \\
\hline \multirow[t]{2}{*}{$6 \sigma$ threshold $^{*}$} & $0.59 \mathrm{ppb}$ & & & Vay et al. (2011) & 0 & Only CO \\
\hline & & & & $\begin{array}{l}\text { Hornbrook et al. (2011) } \\
\text { Holzinger et al. (2005) } \\
\text { Alvarado et al. (2010) } \\
\text { Lewis et al. (2013) } \\
\text { Tereszchuk et al. (2011) } \\
\text { Le Breton et al. (2013) }\end{array}$ & $\begin{array}{r}0 \\
- \\
1.3 \\
0 \\
- \\
-\end{array}$ & $\begin{array}{l}\text { Only CO } \\
\text { No } \mathrm{CH}_{3} \mathrm{CN} \\
\text { Only } \mathrm{CO} \\
\text { No furfural }-\mathrm{CO}<200 \\
\text { No HCN } \\
\text { No HCN }\end{array}$ \\
\hline B619b & 0 & -0.168 & 1.3 & Palmer et al. (2013) & 0 & Only CO \\
\hline \multirow[t]{2}{*}{$6 \sigma$ threshold* } & $0.34 \mathrm{ppb}$ & & & Vay et al. (2011) & 0 & Only CO \\
\hline & & & & $\begin{array}{l}\text { Hornbrook et al. (2011) } \\
\text { Holzinger et al. (2005) } \\
\text { Alvarado et al. (2010) } \\
\text { Lewis et al. (2013) } \\
\text { Tereszchuk et al. (2011) } \\
\text { Le Breton et al. (2013) }\end{array}$ & $\begin{array}{l}0 \\
- \\
0 \\
0 \\
- \\
-\end{array}$ & $\begin{array}{l}\text { Only CO } \\
\text { No } \mathrm{CH}_{3} \mathrm{CN} \\
\text { Only CO } \\
\text { No furfural }-\mathrm{CO}<200 \\
\text { No HCN } \\
\text { No HCN }\end{array}$ \\
\hline B620 & 0 & - & 0 & Palmer et al. (2013) & 0 & Only CO \\
\hline \multirow[t]{2}{*}{$6 \sigma$ threshold* } & $0.41 \mathrm{ppb}$ & & & Vay et al. (2011) & 0 & Only CO \\
\hline & & & & $\begin{array}{l}\text { Hornbrook et al. (2011) } \\
\text { Holzinger et al. (2005) } \\
\text { Alvarado et al. (2010) } \\
\text { Lewis et al. (2013) } \\
\text { Tereszchuk et al. (2011) } \\
\text { Le Breton et al. (2013) }\end{array}$ & $\begin{array}{r}0 \\
- \\
5.1 \\
0 \\
- \\
-\end{array}$ & $\begin{array}{l}\text { Only CO } \\
\text { No } \mathrm{CH}_{3} \mathrm{CN} \\
\text { Only } \mathrm{CO} \\
\text { No furfural }-\mathrm{CO}<200 \\
\text { No HCN } \\
\text { No HCN }\end{array}$ \\
\hline B621a & $0.953 \quad 59.1$ & 0.951 & 77.6 & Palmer et al. (2013) & 58.9 & \\
\hline \multirow[t]{2}{*}{$6 \sigma$ threshold* } & $0.35 \mathrm{ppb}$ & & & Vay et al. (2011) & 23.1 & \\
\hline & & & & $\begin{array}{l}\text { Hornbrook et al. (2011) } \\
\text { Holzinger et al. (2005) } \\
\text { Alvarado et al. (2010) } \\
\text { Lewis et al. (2013) } \\
\text { Tereszchuk et al. (2011) } \\
\text { Le Breton et al. (2013) }\end{array}$ & $\begin{array}{r}32.5 \\
72.3 \\
76.8 \\
- \\
41.6 \\
47.7\end{array}$ & No furfural $-\mathrm{CO}>200$ \\
\hline
\end{tabular}


Table 3. Continued.

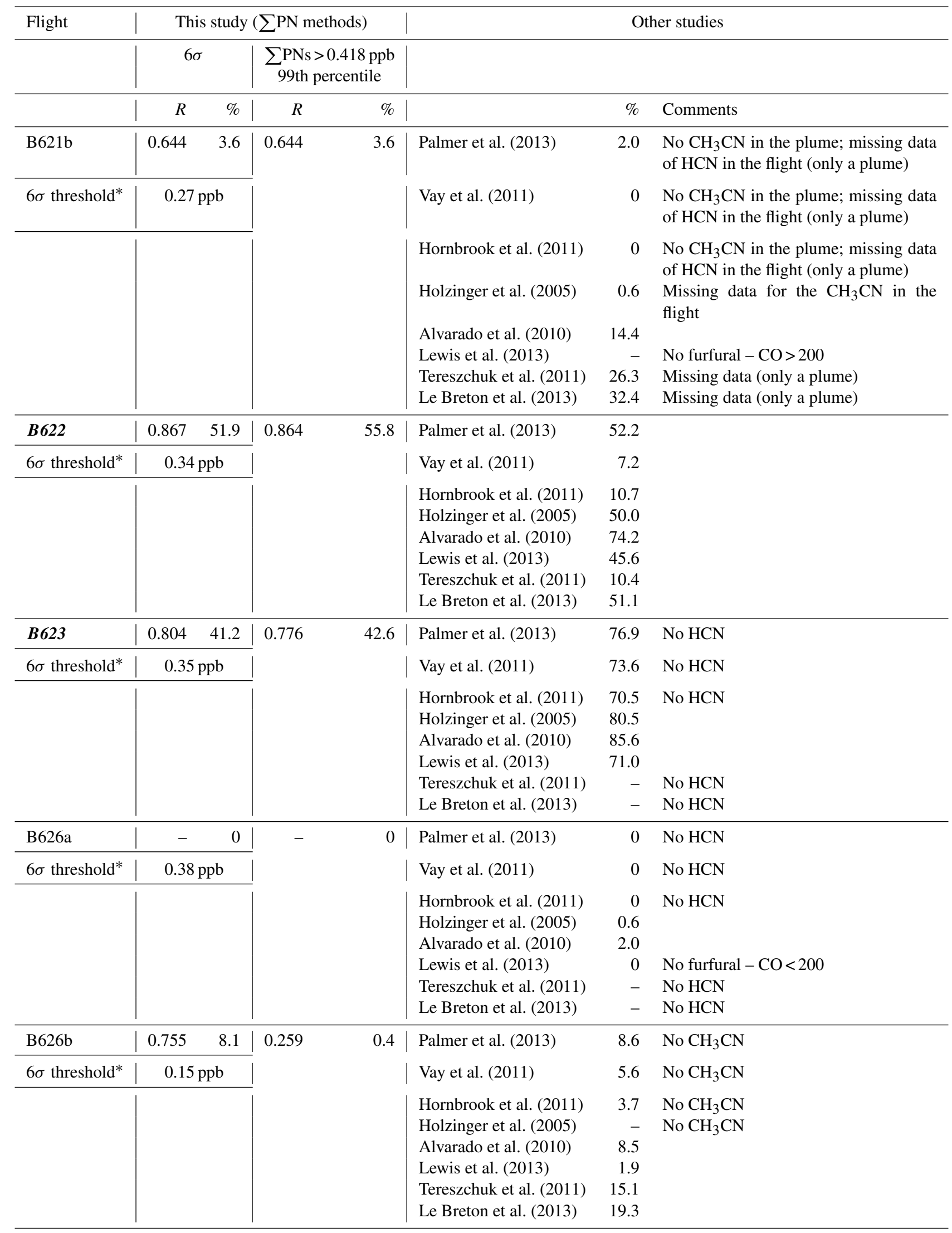


Table 3. Continued.

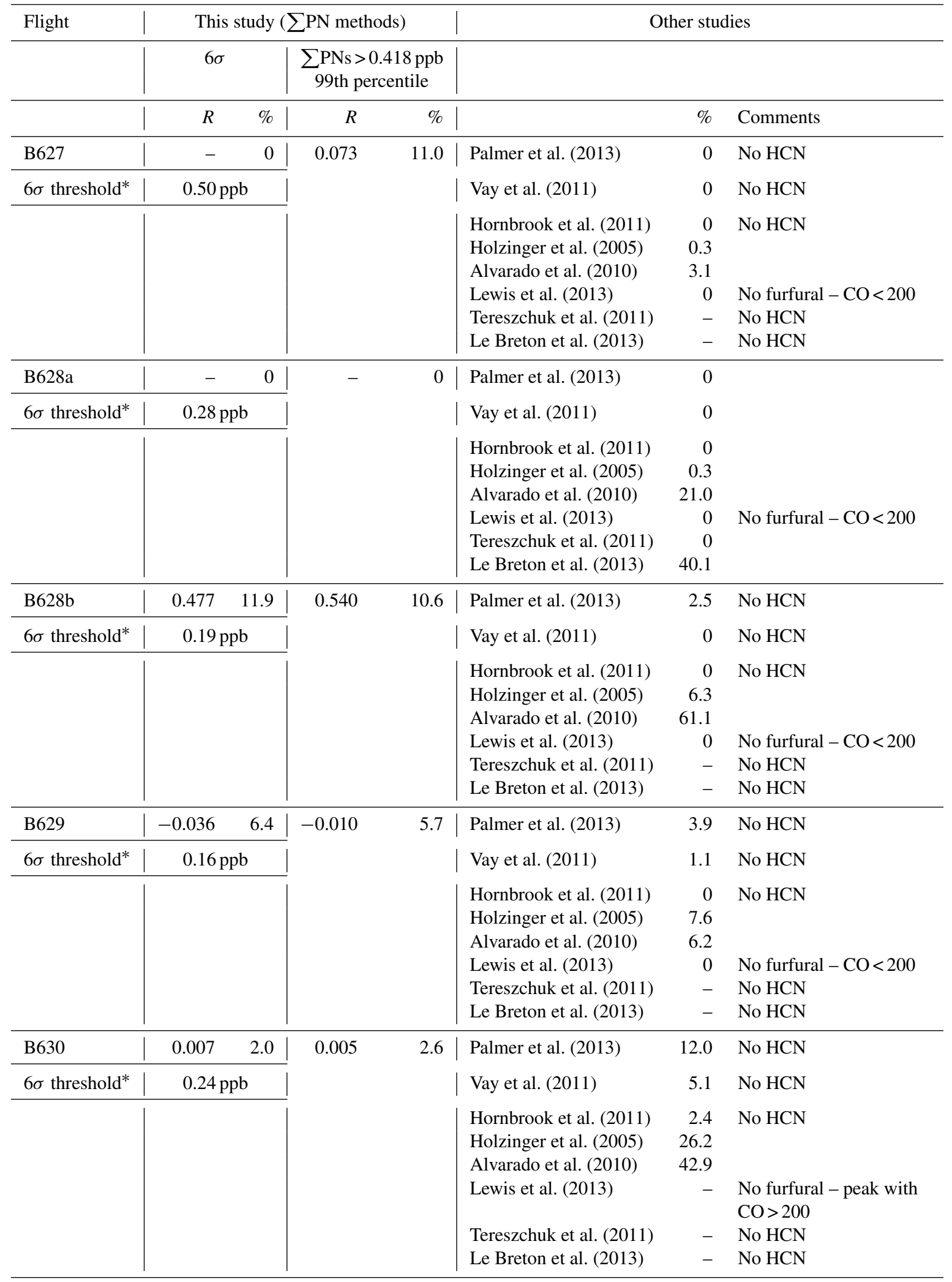

* indication of six times the standard deviation. The percentage of BB plumes is evaluated above the background. 
99th percentile method applied to the $\sum$ PNs for the flights B619a, B619b and B627 shows a small fraction of flight selected as BB. Moreover, the $R$ values between the $\sum \mathrm{PNs}$ and the $\mathrm{CO}$ in those points are so low (or even negative) that they suggest that these parts of the flights are not ascribable as BB plume. The flights B629 and B630 present a small percentage of the flight identified as BB plume, using the $\sum$ PN methods (confirmed also by other methods), but the low (or negative) $R$ values suggest a different origin for these plumes. Summarising, we classified three flights (highlighted in bold-italic in Table 3) with evidence of significant BB plumes sampled, three with a small percentage of BB plumes and eight flights with a dominance of background air masses sampled. Le Breton et al. (2013) evaluated the percentage of flights ascribable as BB plumes using the $6 \sigma$ method applied to their $\mathrm{HCN}$ measurements and the $R^{2}$ between the $\mathrm{CO}$ and the $\mathrm{HCN}$ in the BB plumes for five flights. Our results, with the percentage of flight identified as BB plume using their method, are in agreement with those that they presented, with the exception of the B621 flight. In this case, the difference could be due to the fact that we split the double flights into two datasets and also because for the $\mathrm{B} 621 \mathrm{~b}$ there are some missing data for the $\mathrm{HCN}$ and only one big plume. Moreover, the $R^{2}$ between $\mathrm{HCN}$ and CO range between 0.46 (B622) and 0.83 (B621) (Le Breton et al., 2013). In some flights there is a significant discrepancy between the methods (i.e. the B628) that can be explained by considering that (1) each method uses different thresholds; (2) these thresholds for some methods are fixed for all the campaign, whereas for others they are calculated for each flight; (3) usually air masses are a mixture influenced by different sources (BB, biogenic and anthropogenic) and most of the compounds used as BB tracer are not univocally produced by fires.

Figure 2 shows the scatter plots between the $\sum$ PNs and the $\mathrm{CO}$ for the flights B621a, B622 and B623: the red circles are the $\mathrm{BB}$ plume selected by the $6 \sigma$ of the $\sum \mathrm{PN}$ technique and the black circles the background part of each flight.

The $\sum$ PNs show a very good correlation with the CO, in presence of $\mathrm{BB}$ plumes: the correlation coefficients $R$, in fact, vary between 0.804 and 0.953 . The data of the B623 flight (Fig. 2) show an interesting, distinct double trend between the $\sum \mathrm{PNs}$ and the $\mathrm{CO}$; the time series (Fig. 1) shows that the $\mathrm{CO}$ and the $\mathrm{CH}_{3} \mathrm{CN}$ present two plumes (between $\sim 23.00-23.30$ UTC and $\sim 00.00-00.30$ UTC ) at pressure $(P)$ higher than $\sim 750 \mathrm{hPa}$ (corresponding to an altitude of $\sim 2000 \mathrm{~m}$ a.s.1.). In any case, there is not evidence of a $\sum \mathrm{PN}$ and furfural increase in correspondence of these plumes. In order to explain the double trends in the $\sum \mathrm{PN}$ vs. CO scatter plot with flight B623 (see Fig. 2), we analysed the entire dataset of this flight as function of the pressure, finding that the two trends can be distinguished using a pressure threshold of $750 \mathrm{hPa}$ (Fig. 3) or equivalently an altitude threshold of $\sim 2000 \mathrm{~m}$ a.s.l. (not shown).
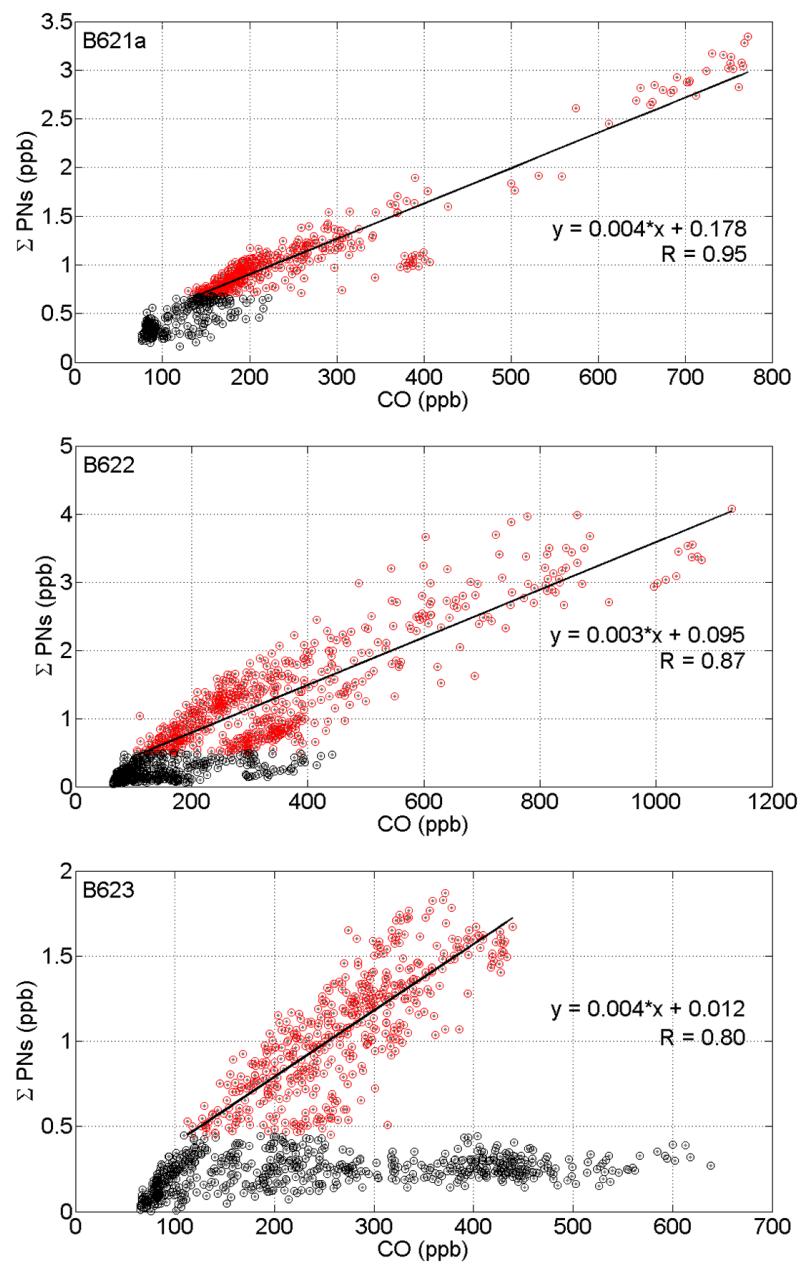

Figure 2. Scatter plot of the $\sum \mathrm{PNs}$ and the $\mathrm{CO}$ for the B621a, B622 and B623 flights (from the top to the bottom, respectively). The red circles indicate the data selected as BB plume using the $6 \sigma$ method to the $\sum \mathrm{PN}$ measurements; the black circles indicate the background air masses.

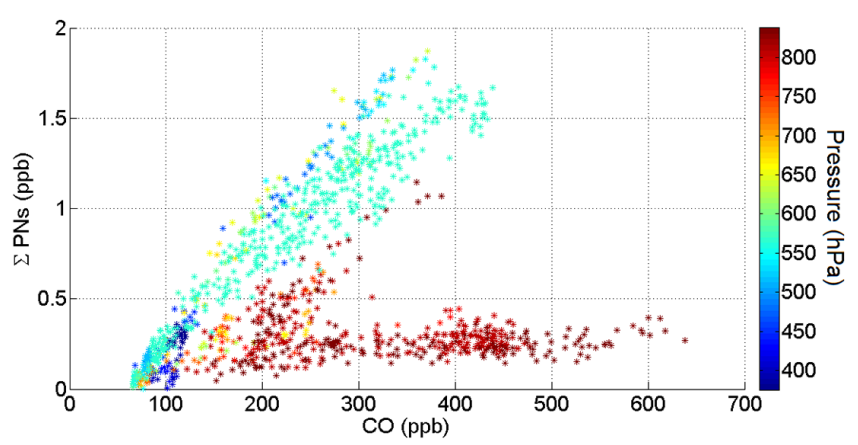

Figure 3. Scatter plot of the $\sum \mathrm{PNs}$ and the $\mathrm{CO}$ as function of the pressure of flight B623. 


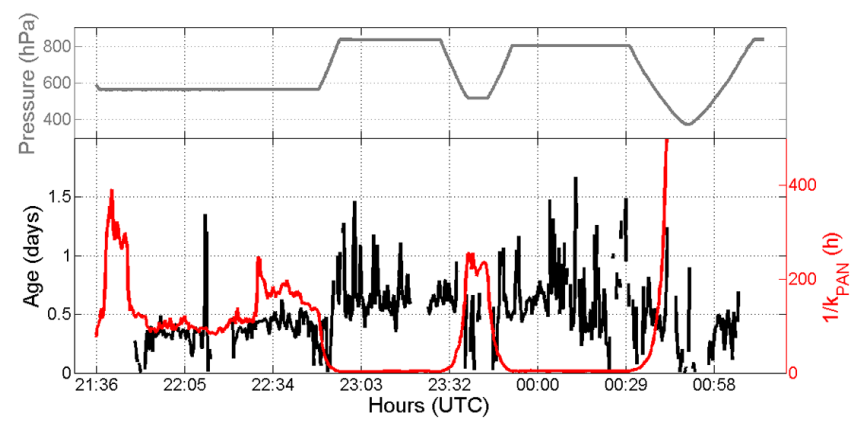

Figure 4. Photochemical age of the air masses (black line) and $1 / k_{\text {PAN }}$ (red line) for flight B623. The pressure is indicated in grey.

The fact that the two distinct trends of flight B623 are separable by the $6 \sigma$ method of the $\sum$ PNs and by pressure led us to examine in depth the correlation between the $\mathrm{CO}$ and the $\sum \mathrm{PNs}$ for all the flights and find that also other flights show similar trends. In fact, the flights B621a and B622 show two different trends that can be distinguished using a pressure threshold of $700 \mathrm{hPa}$ (even if less evident than the B623; figure not shown). The $\sum \mathrm{PNs}$ are thermally decomposed into $\mathrm{NO}_{2}$; in detail, the dominant reaction of thermal decomposition for the PAN (the most abundant and significant of the $\sum \mathrm{PNs}$ in $\mathrm{BB}$ plume) is $\mathrm{CH}_{3} \mathrm{C}(\mathrm{O}) \mathrm{O}_{2} \mathrm{NO}_{2}+\mathrm{M} \rightarrow \mathrm{CH}_{3} \mathrm{C}(\mathrm{O}) \mathrm{O}_{2}+\mathrm{NO}_{2}+\mathrm{M}$ (rate coefficient $k_{\text {PAN }}$ derived from the MCM v.3.3.1). Figure 4 shows the chemical age (days) of the plume and $1 / k_{\text {PAN }}$ expressed in hours (as indication of the thermal lifetime), with the aim to investigate the impact on the double trends between $\sum$ PNs and $\mathrm{CO}$ for flight $\mathrm{B} 623$ of the (1) thermal decomposition of the $\sum$ PNs (lifetime at $P>750 \mathrm{hPa}$ ) and (2) chemical age of the plumes. The age of the air masses has been evaluated using the parent-daughter method: we used the isoprene (parent) and its reaction product MVK. The rate constants for isoprene and MVK with $\mathrm{OH}$ and the branching ratio have been derived by the MCM (v.3.3.1) mechanism. Since the $\mathrm{OH}$ has not been measured during the BORTAS campaign, we used an $\mathrm{OH}$ concentration of $2 \times 10^{6}$ molecules $\mathrm{cm}^{-3}$ as done in other BORTAS paper (Parrington et al., 2013).

The thermal decomposition of PAN as the pressure increases becomes significant; this is an important indication of the different dynamic processes affecting the air masses, suggesting that the air masses at lower pressure (with high $\sum$ PN level) have been interested by pyroconvection and rapidly transported in the upper troposphere. In contrast, the air masses at higher pressure (lower altitude) have spent more time in the boundary layer and the $\sum \mathrm{PNs}$ have been thermally decomposed into $\mathrm{NO}_{2}$ because of the higher temperature in these layers. This allows different chemical regimes in the $\mathrm{NO}_{x}-\mathrm{OH}_{x}$ cycles. In fact, the $\mathrm{NO}_{2}$ at low pressure is not significant (as demonstrated by Alvarado et al. (2010), where it is rapidly converted into PAN in BB plumes) but increases at higher pressure as the $\sum$ PNs decrease: this suggests that
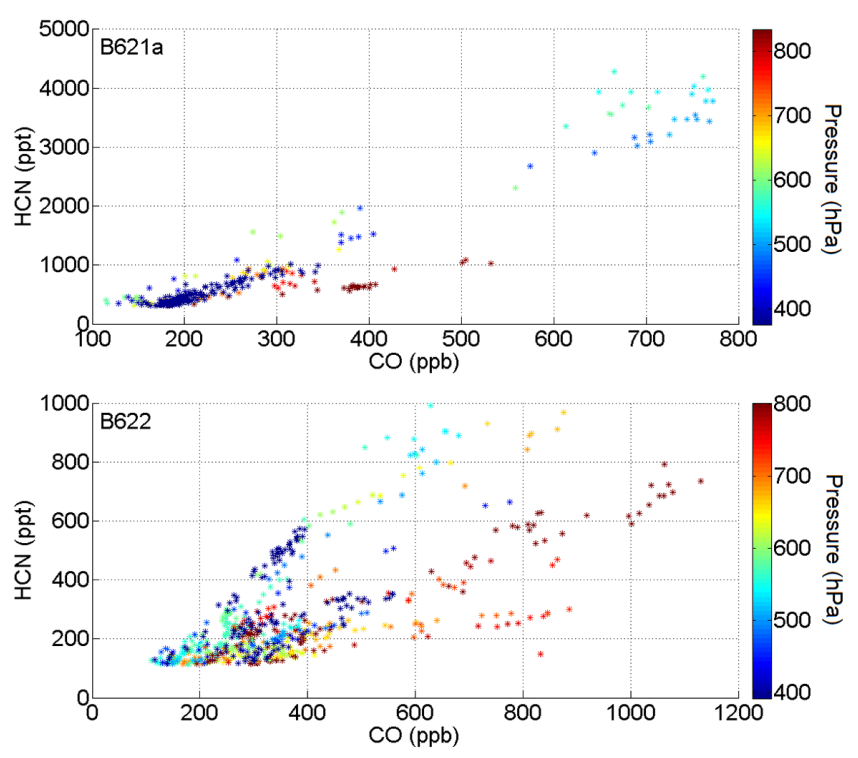

Figure 5. Scatter plot of the $\mathrm{HCN}$ and the $\mathrm{CO}$ as function of the pressure for the flights B621a (at the top) and B622 (at the bottom).

the $\mathrm{NO}_{2}$ at higher pressure is the result of the thermal decomposition of the $\sum$ PNs (Fig. 1). This is very interesting in the $\mathrm{O}_{3}$ investigation downwind of a BB plumes. In this context, the use of the $\sum$ PNs as BB tracer could help to classify the $\mathrm{BB}$ plumes and take into account the different ages of the plumes and the dynamic of the air masses.

Moreover, we also did the same analysis for the HCN: we found that for the flights B621a and B622 the scatter plot (plotting only the data selected as BB plume using the Le Breton et al. (2013) method) of the HCN and the CO shows different trends that can be distinguishable by the pressure (Fig. 5). Even if the double trends between $\sum$ PNs and $\mathrm{CO}$ for the B623 flight were influenced by its thermal lifetime and by the age of the air masses, the fact that the $\mathrm{HCN}$, a long-lived species, shows different trends as a function of the $\mathrm{CO}$ for the flights B621a and B622 (Fig. 5) suggested to us that the air masses we sampled at $P>750 \mathrm{hPa}$ were influenced by other sources in addition to the BB emissions (Crounse et al., 2009; Moussa et al., 2016) in these flights. Considering that for the B623 the pressure threshold is similar to that of the B621a and B622 and that flight B622 occurred in the same day of the B623, we concluded that also the air masses sampled during flight B623 at $P>750 \mathrm{hPa}$ could be influenced by other sources.

To prove this thesis, we evaluated the Lagrangian back trajectories (HYSPLIT model; Draxler et al., 1999) by selecting the starting point at different altitudes along the flight trajectory and running the model up to $200 \mathrm{~h}$ back. The meteorology used to drive the HYSPLIT back trajectories has been downloaded from the NCAR/NCEP $2.5^{\circ}$ global reanalysis archive (available at the ARL server). Figure 6c shows the back trajectories of air masses sampled at pres- 

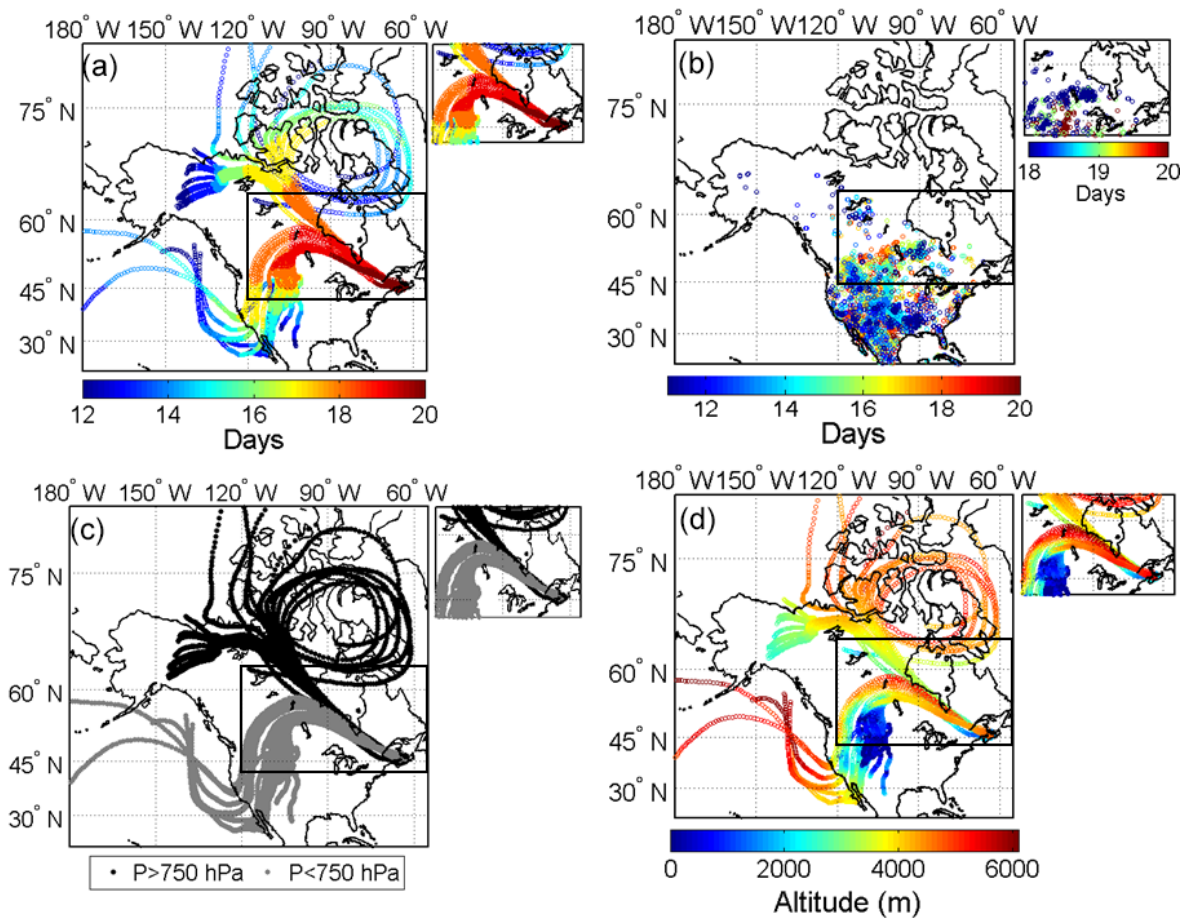

Figure 6. (a) Temporal position (express as day from 12 to 20 July) along the $200 \mathrm{~h}$ back trajectories. (b) Spot of the biomass burning fires derived from the FLAMBE archive as function of the day in which they occurred (from 11 to 20 July - we selected the dataset at 13:00 and the 23:00 UTC). (c) Back trajectories for starting points along the flight trajectories at $P>750 \mathrm{hPa}$ (black) and $P<750 \mathrm{hPa}$ (grey). (d) Altitude along the back trajectories.

sure higher than $750 \mathrm{hPa}$ (black points) or lower than $750 \mathrm{hPa}$ (grey points): a different origin is clearly identifiable. In particular, air masses collected at lower altitudes $(P>750 \mathrm{hPa})$ come from the northern region of Canada and the altitude of provenance increases the further back the trajectory goes and decreases in the last 3 days of simulation (Fig. 6d); in contrast, the air masses corresponding to $P<750 \mathrm{hPa}$ originated in the south-western region of the Canada (e.g. Alberta, Saskatchewan) and in the north-western states of the USA (e.g. Montana, Idaho, Wyoming, Washington, Oregon). Figure 6a represents the position of the air masses along the back trajectories during the days between the 12 and 20 July (corresponding to $-200 \mathrm{~h}$ back and $0 \mathrm{~h}$ back in the back-trajectory model setup). In the same way, Fig. $6 \mathrm{~b}$ shows the fire spots recorded by the FLAMBE (The Fire Locating And Monitoring of Burning Emissions; Reid et al., 2009) archives, which incorporates the fire products from the NASA Moderate-Resolution Imaging Spectroradiometer (MODIS) instrument, as a function of the day on which the biomass burning occurred (between 11 and 20 July). Figure 6 reveals not only that air masses collected for $P>750 \mathrm{hPa}$ come from a different region of the North America respect to those collected for $P<750 \mathrm{hPa}$ but also that the regions of interest for air masses at $P>750 \mathrm{hPa}$ are, most likely, not impacted by fire emissions, at least for the days in which the air masses passed over those areas. In contrast, the plumes (iden- tified as BB plumes) measured at $P<750 \mathrm{hPa}$ (i.e. altitude higher than $2000 \mathrm{~m}$ a.s.l.) originated from regions strongly influenced by biomass burning fires (see panel b of Fig. 6) on the central-west coast of the North America) on the days in July when the air masses flew above those territories. The back-trajectory analysis, therefore, confirms the existence of two different layers of air masses sampled during the B623 flight, distinguishable by the pressure (i.e. the altitude). In light of the photochemical age of the air masses, we highlighted the back trajectories between 18 and 20 July 2011 (panels in the upper right corners in Fig. 6) and the fires to the east of Winnipeg Lake (Manitoba) that occurred on the same days and should be a source of the air masses sampled during flight $\mathrm{B} 623$. Anyway, doubling the $\mathrm{OH}$ concentrations halved the age of the air masses $(\sim 12-24 \mathrm{~h}$ for air masses at $P>750 \mathrm{hPa}$ ); however, halving the $\mathrm{OH}$ concentrations doubled the age ( $\sim 2.5-3$ days). In the last case the air masses at $P>750 \mathrm{hPa}$ come from a region significantly less influenced by fires in comparison to the plumes at $P<750 \mathrm{hPa}$.

In conclusion, we described different methods employed for the identification of the BB plumes, highlighting that the use of only one of these methods may not be always optimal. In some cases, in fact, the trace species utilised were not available (such as the HCN measured only for 5 flights of the total 16 flights or the furfural/furan); moreover, the use of a fixed threshold for all the flights of a single species 
Table 4. Indices to evaluate the model performances. $R$ is the correlation coefficient, FB is the fractional bias, NMSE is the normalised mean squared error and FA2 the factor of 2. See the text for a description of these indices. In italic are the results obtained including the pressure to the inputs.

\begin{tabular}{llrrrr}
\hline & Simulations & $R$ & FB & NMSE & FA2 \\
\hline \multirow{2}{*}{ PNNs (B622) } & Case A & 0.94 & -0.017 & 0.124 & 0.755 \\
& Case B & 0.95 & -0.023 & 0.099 & 0.763 \\
\hline \multirow{2}{*}{ HCN (B622) } & Case A & 0.86 & 0.009 & 0.228 & 0.946 \\
& Case B & 0.92 & 0.014 & 0.136 & 0.959 \\
\hline \multirow{2}{*}{ PNs (B623) } & Case A & 0.77 & 0.014 & 0.028 & 0.771 \\
& Case B & 0.94 & $-8.8 \times 10^{-4}$ & 0.079 & 0.867 \\
\hline
\end{tabular}

can show discrepancies respect to other methods. Our main conclusion is that all the methods can have limitations; therefore using only one of them can sometimes produce a false positive in BB identification. We suggest, for a better BB identification and description, using a set of methods (using different species such as $\mathrm{CO}, \mathrm{HCN}, \mathrm{CH}_{3} \mathrm{CN}$, furfural/furan and $\sum \mathrm{PNs}$ ) to select the BB plume. After the identification, the use of the $\sum$ PNs (and furfural) coupled with a physical parameter (especially in aircraft campaign) allows one to describe the ages of the plumes and the dynamic of the air masses: the presence of the $\sum$ PNs is an indication of lower ages of the air masses and of their permanence at higher altitudes after the emission.

The $\sum$ PNs, however, present some limitations: (1) as with other species, they can be affected by other sources besides BB emissions; (2) the dependence of their lifetime on physical parameters (i.e. temperature).

\section{Model results}

In order to refine the methods to discriminate the BB plumes and better understand the origin of the air masses analysed in the BORTAS campaign, an ANN model, recently developed for $\mathrm{O}_{3}$ studies (Biancofiore et al., 2015), has been adapted and used with BORTAS dataset. ANNs are mathematical techniques used to analyse the relationship among various variables and predict the outcome of a response variable. ANNs are composed by a number of interconnected artificial neurons or nodes, in a way similar to the biological nervous systems (Vemuri, 1988; Braspenning and Thuijsman, 1995). The nodes are connected with each other and are generally set in layers: the input layer, one or more hidden layers and the output layer. The nodes of input layer retain the information of the predictors and then the information is transmitted to the hidden layers where it is weighted and transformed by activation and transfer functions, until reaching the output layer that provides the predicted quantity. ANNs are capable of learning via a process of calibration usually called training; that process is carried out, minimising the errors committed during the training (Hecht-Nielsen, 1991).
The ANNs are able to reproduce the evolution of compounds that have complex chemistry and sometimes non-linear relationship with others (Lonbladd et al., 1992); for this reason the ANNs are ideal to investigate the relation between $\sum$ PNs (and $\mathrm{HCN}$ ) and chemical and physical parameters. In this work, a recurrent architecture was used (Elman, 1990). In the Elman architecture the information contained in the hidden layers are back-propagated in the input layer that provides a multi-step memory. We simulated the concentrations of the $\sum$ PNs for the B623 flight and of the $\sum$ PNs and the $\mathrm{HCN}$ for the B622. During both these flights the scatter plots between the $\sum \mathrm{PNs}$ and the $\mathrm{CO}$ or the $\mathrm{HCN}$ and the $\mathrm{CO}$ show different trends that we distinguished by the pressure and that are indicative of air masses having different origins (coming from regions impacted mainly by fires or not), as explained in Sect. 3. We carried out two different simulations: (a) we used as input for the neural network only the $\mathrm{O}_{3}, \mathrm{CO}, \mathrm{NO}$ and $\mathrm{CH}_{3} \mathrm{CN}$ (case A); (b) we used as input the $\mathrm{O}_{3}, \mathrm{CO}, \mathrm{NO}$, $\mathrm{CH}_{3} \mathrm{CN}$ and the pressure (case $\mathrm{B}$ ). In this way, we evaluated if and how the simulations of the $\sum$ PNs and the HCN change by adding a physical parameter to the inputs, therefore taking into account the position of the air masses (i.e. the altitude of the aircraft during the flights).

Figure $8 \mathrm{a}$ and $\mathrm{b}$ show the results of the case A simulations for flight B622: the scatter plot of the simulated HCN (panel a) and $\sum$ PNs (panel b) against the measured $\mathrm{CO}$ as function of the pressure does not present distinct trends as evident in the measured data. Similar results have been found for the case A simulations (panel c in Fig. 8) of flight B623: the net separation of two trends in the $\sum \mathrm{PN}$ vs. CO scatter plot of the measured data (Fig. 3) is not reproduced by the model. In contrast, adding the pressure to the inputs (case B) improves the simulations significantly for both the flights and both the species. Figure 9 shows the ANN simulations in case B. It is evident that the different trends, identifiable by the pressure using the measured data (Figs. 3 and 5), are well reproduced and become evident despite what occurred in case A (Fig. 8). Moreover, it is clear also that the correlation coefficients between the $\sum$ PNs measured and the $\sum$ PNs simulated increase adding the pressure to the inputs (these results are highlighted in italic in Table 4): in fact, $R$ improves from 0.94 (case A) to 0.95 (case B) for the B622 flight and, even more, from 0.77 (case A) to 0.94 (case B) for flight $\mathrm{B} 623$, in which the two trends between the $\sum \mathrm{PNs}$ and the $\mathrm{CO}$ are significantly more evident with respect to the $\mathrm{B} 622$ flight. Similar results can be found for the HCN: the correlation coefficient $R$, in fact, increases from 0.86 (case $\mathrm{A}$ ) to 0.92 (case B). In addition to the correlation coefficient $R$, we estimated the model performances using three more typical indices (Biancofiore et al., 2015): the fractional bias (FB), the normalised mean squared error (NMSE) and the factor of 2 (FA2). The results are summarised in Table 4 . The FB is calculated as the ratio between the difference of the mean observed and the mean modelled concentrations and their 

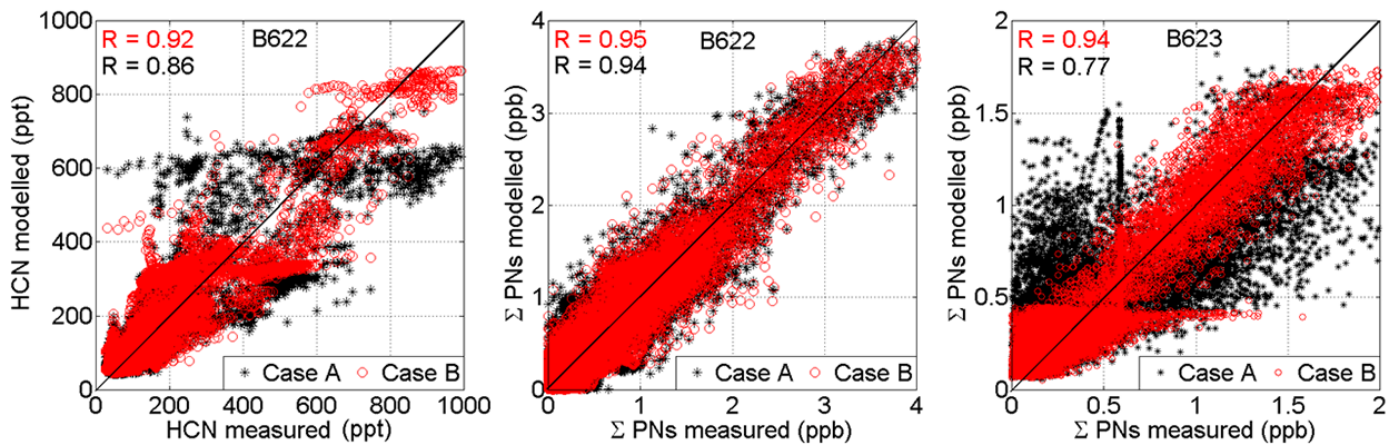

Figure 7. Scatter plots (from left): HCN modelled vs. HCN measured (cases A and B) for flight B622; $\sum$ PNs measured vs. $\sum$ PNs modelled (cases A and B) for flight B622; $\sum$ PNs measured vs. $\sum$ PNs modelled (cases A and B) for flight B623.
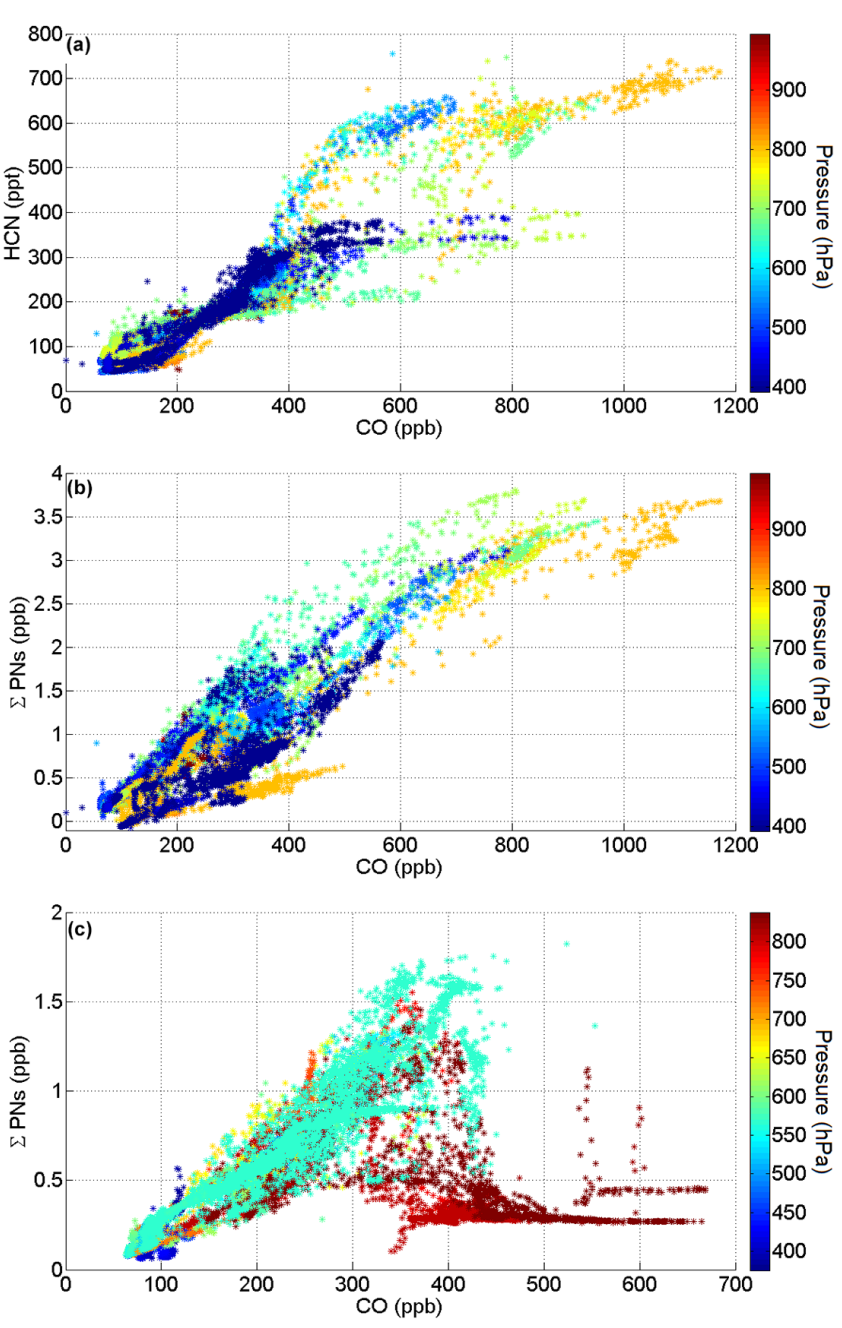

Figure 8. Simulation results for case $\mathrm{A}$ (only $\mathrm{O}_{3}, \mathrm{CO}, \mathrm{NO}$ and $\mathrm{CH}_{3} \mathrm{CN}$ as inputs): scatter plots of simulated $\mathrm{HCN}$ and measured $\mathrm{CO}$ for flight B622 (a); simulated $\sum \mathrm{PNs}$ and measured $\mathrm{CO}$ (b) for B622; simulated $\sum$ PNs and measured CO for B623 (c). mean:

$\mathrm{FB}=\frac{\overline{C_{\mathrm{o}}}-\overline{C_{\mathrm{s}}}}{\left(\overline{C_{\mathrm{o}}}+\overline{C_{\mathrm{s}}}\right) \cdot 0.5}$.

It indicates the systemic errors that can create a bias between the modelled and the measured data and can range between -2 (overestimation) and +2 (underestimation). An ideal model has an FB index of zero. The NMSE is the result of the ratio between the mean of the squared difference between the observed and the modelled concentrations and the sum of their mean; it gives information about the total errors of the models and the best value is 0 (as the NMSE decreases approaching 0 , the model performance increases).

$\mathrm{NMSE}=\frac{\overline{\left(C_{\mathrm{o}}-C_{\mathrm{s}}\right)^{2}}}{\overline{C_{\mathrm{o}}} \cdot \overline{C_{\mathrm{s}}}}$

Finally, the FA2 is the percentage of the simulated data for which the ratio between the observed and the modelled concentrations is included between 0.5 and 2 :

$\mathrm{FA} 2=0.5 \leq \frac{C_{\mathrm{o}}}{C_{\mathrm{s}}} \leq 2$.

The ideal model has an FA2 of 1 and the worst results occur if FA2 is equal to zero. The $\sum$ PN simulation for flight B622 shows that $R$, NMSE and the FA2 improve, adding the pressure to the inputs (case $\mathrm{B}$ ); in contrast, the FB results are slightly worse, indicating that the model tends to overestimate the concentrations. The $\mathrm{HCN}$ simulation for flight B622 has better results for all the indices with the exception, also in this case, of the FB, which is slightly greater in case B than in case A. Finally, the $R, \mathrm{FB}$ and FA2 of the $\sum \mathrm{PNs}$ modelled for flight B623 show a significant improvement in case $B$ respect case $A$, but the NMSE presents a worsening that suggests the possibility of an increase in the random errors. Figure 7 shows the scatter plots of the measured and modelled $\mathrm{HCN}$ in cases A (black asterisks) and B (red circles) for flight B622 and of measured and modelled $\sum$ PNs for both flight B622 and B623. 

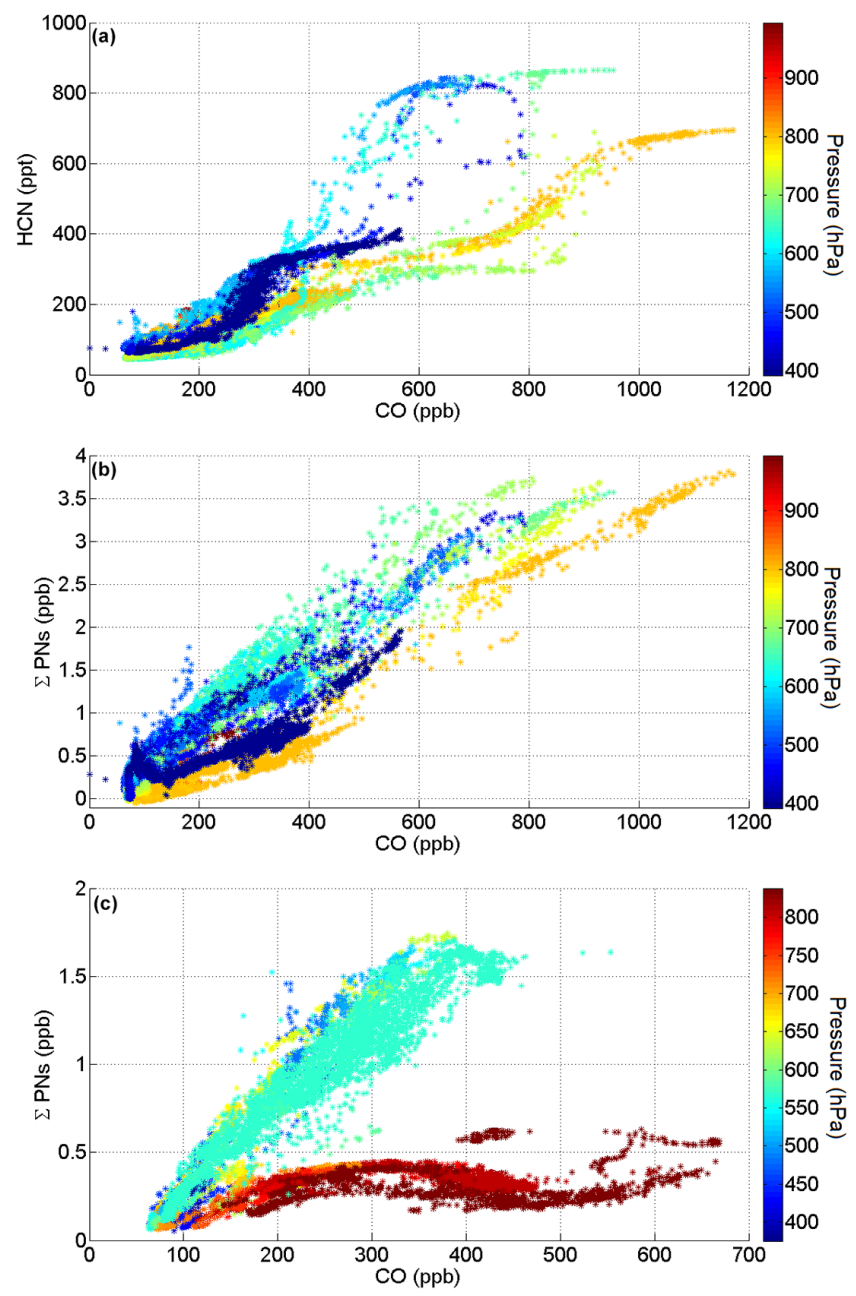

Figure 9. Simulation results for case $\mathrm{B}\left(\mathrm{O}_{3}, \mathrm{CO}, \mathrm{NO}, \mathrm{CH}_{3} \mathrm{CN}\right.$ and pressure as inputs): scatter plots of simulated $\mathrm{HCN}$ and measured $\mathrm{CO}$ for flight B622 (a); simulated $\sum \mathrm{PNs}$ and measured $\mathrm{CO}$ (b) for B622; simulated $\sum$ PNs and measured CO for B623 (c).

\section{Conclusions}

The measured $\sum$ PNs during the BORTAS aircraft campaign show a good correlation $(R$ varying between $\sim 0.80$ and $\sim 0.95$ ) with $\mathrm{CO}$ for different flights. We used $\sum \mathrm{PNs}$ as BB tracers and applied two different methods to select a BB plumes: (1) we defined a threshold of $6 \sigma$ of $\sum \mathrm{PN}$ concentration for each flight and all the data that are $6 \sigma$ times higher than the background level have been selected as BB plume; (2) evaluating the 99th percentile of the $\sum \mathrm{PN}$ measurements done during the B625 flight (considered a background flight not affected by BB plumes). Moreover, we applied several methods present in the literature to our dataset to compare them with the proposed $\sum \mathrm{PN}$ methods and we calculated the percentage of flight classifiable as BB plume; we found that all the methods identified three flights with evident and significant percentage of BB plumes intercepted. Therefore for most of the flights the $\sum \mathrm{PN}$ methods is in agreement with the other methods. However, we found that all the methods might have some limitations (i.e. the availability of the data such as furfural or $\mathrm{HCN}$ or false positive identified using a fixed threshold for all the campaign). The $\sum$ PNs present some limitations due to their thermal dissociation into $\mathrm{NO}_{2}$ that reduces their lifetime as the temperature increases, i.e. as the altitude decreases. In some flights, in fact, the scatter plot of the $\sum \mathrm{PNs}$ and the $\mathrm{CO}$ shows different slopes; even if this trend were due to the change of the $\sum$ PN lifetime with the altitude and to the age of the air masses identifiable by a pressure threshold, the fact that the $\mathrm{HCN}$ also shows, even if in other flights, similar trends with the $\mathrm{CO}$ dependent on the pressure suggested that the air masses sampled could be spatially (vertically) different and that they could be impacted by different sources other than BB. In order to refine the method we adapted an ANN model simulating the $\sum \mathrm{PNs}$ and the $\mathrm{HCN}$ in two different ways: (1) using only the $\mathrm{CO}, \mathrm{NO}, \mathrm{O}_{3}$ and $\mathrm{CH}_{3} \mathrm{CN}$ as inputs; (2) adding the pressure to the inputs as well. We found that the model results improve in the second case. In conclusion, we suggest using a combination of methods (i.e. use different BB tracers, such as $\mathrm{CO}, \mathrm{CH}_{3} \mathrm{CH}, \mathrm{HCN}$, furfural and $\sum \mathrm{PNs}$ ) coupled with a meteorological parameter (such as pressure, especially during aircraft campaigns) for the identification of BB plumes and the characterisation of the BB plumes. In conclusion, the $\sum$ PNs provide an indication about the age and the dynamic of the air masses.

\section{Data availability}

Data used for this analysis are available at the BORTAS section of the Centre for Environmental Data Analysis (http://catalogue.ceda.ac.uk/uuid/ 68e8b5b9feee0ea5d99002b489c87041, CEDA, 2011).

Acknowledgements. The BORTAS project was supported by the Natural Environment Research Council (NERC) under grant number NE/F017391/1. This work was partially supported by funds for open-access publication of the Department of Psychological, Health and Territorial Sciences, University "G. d'Annunzio" of Chieti-Pescara.

Edited by: T. F. Hanisco

Reviewed by: three anonymous referees

\section{References}

Alvarado, M. J., Logan, J. A., Mao, J., Apel, E., Riemer, D., Blake, D., Cohen, R. C., Min, K.-E., Perring, A. E., Browne, E. C., Wooldridge, P. J., Diskin, G. S., Sachse, G. W., Fuelberg, H., Sessions, W. R., Harrigan, D. L., Huey, G., Liao, J., Case-Hanks, A., Jimenez, J. L., Cubison, M. J., Vay, S. A., Weinheimer, A. 
J., Knapp, D. J., Montzka, D. D., Flocke, F. M., Pollack, I. B., Wennberg, P. O., Kurten, A., Crounse, J., Clair, J. M. St., Wisthaler, A., Mikoviny, T., Yantosca, R. M., Carouge, C. C., and Le Sager, P.: Nitrogen oxides and PAN in plumes from boreal fires during ARCTAS-B and their impact on ozone: an integrated analysis of aircraft and satellite observations, Atmos. Chem. Phys., 10, 9739-9760, doi:10.5194/acp-10-9739-2010, 2010.

Andreae, M. O. and Merlet, P.: Emission of trace gases and aerosols from biomass burning, Global Biogeochem. Cy., 15, 955-966, 2001.

Biancofiore, F., Verdecchia, M., Di Carlo, P., Tomassetti, B., Aruffo, E., Busilacchio, M., Bianco, S., Di Tommaso, S., and Colangeli, C.: Analysis of surface ozone using a recurrent neural network, Sci. Total. Environ., 514, 379-387, 2015.

Bertschi, I. T., Jaffe, D. A., Jaeglé, L., Price, H. U., and Dennison, J. B.: PHOBEA/ITCT 2002 airborne observations of transPacific transport of ozone, CO, VOCs, and aerosols to the northeast Pacific: Impacts of Asian anthropogenic emissions and Siberian boreal fire emissions, J. Geophys. Res., 109, D23S12, doi:10.1029/2003JD004328, 2004.

Braspenning, P. J. , Thuijsman, F., and Weijters, A. J. M. M.: Artificial Neural Net-works, an Introduction to ANN Theory and Practice. Lecture Notes on Computer Science, 931, Springer, Berlin, ISBN-10: 3540594884, 1995.

CEDA: Centre for Environmental Data Analysis, BORTAS section, available at: http://catalogue.ceda.ac.uk/uuid/ 68e8b5b9feee0ea5d99002b489c87041, 2011.

Cofer III, W. R., Winstead, E. L., Stocks, B. J., Goldammer, J. G., and Cahoon, D. R.: Crown fire emissions of $\mathrm{CO}_{2}, \mathrm{CO}, \mathrm{H}_{2}, \mathrm{CH}_{4}$, and TNMHC from a dense jack pine boreal forest fire, Geophys. Res. Lett., 25, 3919-3922, 1998.

Crounse, J. D., DeCarlo, P. F., Blake, D. R., Emmons, L. K., Campos, T. L., Apel, E. C., Clarke, A. D., Weinheimer, A. J., McCabe, D. C., Yokelson, R. J., Jimenez, J. L., and Wennberg, P. O.: Biomass burning and urban air pollution over the Central Mexican Plateau, Atmos. Chem. Phys., 9, 4929-4944, doi:10.5194/acp-9-4929-2009, 2009.

Crutzen, P. J. and Andreae, M. O.: Biomass Burning in the Tropics: Impact on Atmospheric Chemistry and Biogeochemical Cycles, Science, 250, 669-1678, 1990.

Crutzen, P. J., Heidt, L. E., Krasnec, J. P., Pollock W. H., and Seiler, W.: Biomass burning as a source of atmospheric gases $\mathrm{CO}, \mathrm{H}_{2}$, $\mathrm{N}_{2} \mathrm{O}, \mathrm{NO}, \mathrm{CH}_{3} \mathrm{Cl}$ and COS, Nature, 282, 253-256, 1979.

Dari-Salisburgo, C., Carlo, P. D., Giammaria, F., Kajii, Y., and D'Altorio, A.: Laser induced fluorescence instrument for $\mathrm{NO}_{2}$ measurements: Observations at a central Italy background site, Atmos. Environ., 43, 970-977, 2009.

Day, D. A., Wooldridge, P. J., Dillon, M. B., Thornton, J. A., and Cohen, R. C.: A thermal dissociation laser-induced fluorescence instrument for in-situ detection of $\mathrm{NO}_{2}$, peroxy nitrates, alkyl nitrates, and $\mathrm{HNO}_{3}$, J. Geophys. Res., 107, 4046, doi:10.1029/2001JD000779, 2002.

Dibb, J. E., Talbot, R. W., Scheuer, E. M., Seid, G., Avery, M. A., and Singh, H. B.: Aerosol chemical composition in Asian continental outflow during the TRACE-P campaign: Comparison with PEM-West B, J. Geophys. Res., 108, 8815, doi:10.1029/2002JD003111, 2003.

Di Carlo, P., Aruffo, E., Busilacchio, M., Giammaria, F., DariSalisburgo, C., Biancofiore, F., Visconti, G., Lee, J., Moller,
S., Reeves, C. E., Bauguitte, S., Forster, G., Jones, R. L., and Ouyang, B.: Aircraft based four-channel thermal dissociation laser induced fluorescence instrument for simultaneous measurements of $\mathrm{NO}_{2}$, total peroxy nitrate, total alkyl nitrate, and $\mathrm{HNO}_{3}$, Atmos. Meas. Tech., 6, 971-980, doi:10.5194/amt-6-971-2013, 2013.

Draxler, R. R.: HYSPLIT4 user's guide, Tech. Rep. NOAA Tech. Memo. ERL ARL-230, NOAA Air Resources Laboratory, Silver Spring, MD, 1999.

Elman, L. J.: Finding structure in time, Cognitive Sci., 14, 179-211, 1990.

Gerbig, C., Schmitgen, S., Kley, D., Volz-Thomas, A., Dewey, K., and Haaks, D.: An improved fast-response vacuumUVresonance fluorescence CO instrument, J. Geophys. Res., 104, 1699-1704, 1999.

Gillett, N., Weaver, A. J., Zwiers, F. W., and Flannigan, M. D.: Detecting the effect of climate change on Canadian forest fires, Geophys. Res. Lett., 31, L18211, doi:10.1029/2004GL020876, 2004.

Goode, J. G., Yokelson, R. J., Ward, D. E., Susott, R. A., Babbitt, R. E., Davies, M. A., and Hao, W. M.: Measurements of Excess $\mathrm{O}_{3}, \mathrm{CO}_{2}, \mathrm{CO}, \mathrm{CH}_{4}, \mathrm{C}_{2} \mathrm{H}_{4}, \mathrm{C}_{2} \mathrm{H}_{2}, \mathrm{HCN}, \mathrm{NO}, \mathrm{NH}_{3}$, $\mathrm{HCOOH}, \mathrm{CH}_{3} \mathrm{COOH}, \mathrm{HCHO}$ and $\mathrm{CH}_{3} \mathrm{OH}$ in 1997 Alaskan Biomass Burning Plumes by Airborne Fourier Transform Infrared Spectroscopy (AFTIR), J. Geophys. Res., 105, 2214722166, 2000.

Hecht-Nielsen, R.: Neurocomputing, Addison Wesley Publishing Company, 433 pp., ISBN-10: 0201093553, 1990.

Holzinger, R., Williams, J., Salisbury, G., Klüpfel, T., de Reus, M., Traub, M., Crutzen, P. J., and Lelieveld, J.: Oxygenated compounds in aged biomass burning plumes over the Eastern Mediterranean: evidence for strong secondary production of methanol and acetone, Atmos. Chem. Phys., 5, 39-46, doi:10.5194/acp-5-39-2005, 2005.

Hopkins, J. R., Read, K. A., and Lewis, A. C.: Two column method for long-term monitoring of non-methane hydrocarbons (NMHCs) and oxygenated volatile organic compounds, J. Environ. Monitor., 5, 8-13, 2003.

Hornbrook, R. S., Blake, D. R., Diskin, G. S., Fried, A., Fuelberg, H. E., Meinardi, S., Mikoviny, T., Richter, D., Sachse, G. W., Vay, S. A., Walega, J., Weibring, P., Weinheimer, A. J., Wiedinmyer, C., Wisthaler, A., Hills, A., Riemer, D. D., and Apel, E. C.: Observations of nonmethane organic compounds during ARCTAS - Part 1: Biomass burning emissions and plume enhancements, Atmos. Chem. Phys., 11, 11103-11130, doi:10.5194/acp11-11103-2011, 2011.

Hudman, R. C., Jacob, D. J., Turquety, S., Leibensperger, E. M., Murray, L. T., Wu, S., Gilliland, A., Avery, M., Bertram, T., Brune, W., Cohen, R., Dibb, J., Flocke, F., Firied, A., Holloway, J., Neuman, J., Orville, R., Perring, A., Ren, X., Sachse, G., Singh, H., Swanson, A., and Wooldridge, P.: Surface and lighning sources of nitrogen oxides over the United States: Magnitudes, chemical evolution, and outflow, J. Geophys. Res., 112, D12S05, doi:10.1029/2006JD007912, 2007.

Jacob, D. J., Wofsy, S. C., Bakwin, P. S., Fan, S.-M., Harriss, R. C., Talbot, R. W., Bradshaw, J., Sandholm, S., Singh, H. B., Gregory, G. L., Browell, E. V., Sachse, G. W., Blake, D. R., and Fitzjarrald, D. R.: Summertime photochemistry at high northern latitudes, J. Geophys. Res., 97, 16421-16431, 1992. 
Jaffe, D. A. and Wigder, N. L.: Ozone production from wildfires: A critical review, Atmos. Environ., 51, 1-10, doi:10.1016/j.atmosenv.2011.11.063, 2012.

Lavoué, D., Liousse, C., Cachier, H., Stocks, B. J., and Goldammer, J. G..: Modeling of carbonaceous particles emitted by boreal and temperate wildfires at northern latitudes, J. Geophys. Res.Atmos., 105, 26871-26890, 2000.

Le Breton, M., Bacak, A., Muller, J. B. A., O'Shea, S. J., Xiao, P., Ashfold, M. N. R., Cooke, M. C., Batt, R., Shallcross, D. E., Oram, D. E., Forster, G., Bauguitte, S. J.-B., Palmer, P. I., Parrington, M., Lewis, A. C., Lee, J. D., and Percival, C. J.: Airborne hydrogen cyanide measurements using a chemical ionisation mass spectrometer for the plume identification of biomass burning forest fires, Atmos. Chem. Phys., 13, 92179232, doi:10.5194/acp-13-9217-2013, 2013.

Lee, J. D., Moller, D. J., Read, K. A., Lewis, A. C., Mendes, L., and Carpenter, L. J.: Year-round measurements of nitrogen oxides and ozone in the tropical North Atlantic marine boundary layer, J. Geophys. Res., 114, D21302, doi:10.1029/2009JD011878, 2009.

Leung, F.-Y. T., Logan, J. A., Park, R., Hyer, E., Kasischke, E., Streets, D., and Yurganov, L.: Impacts of enhanced biomass burning in the boreal forests in 1998 on tropospheric chemistry and the sensitivity of model results to the injection height of emissions, J. Geophys. Res., 112, D10313, doi:10.1029/2006JD008132, 2007.

Lewis, A. C., Evans, M. J., Methven, J., Watson, N., Lee, J. D., Hopkins, J. R., Purvis, R. M., Arnold, S. R., McQuaid, J. B., Whalley, L. K., Pilling, M. J., Heard, D. E., Monks, P. S., Parker, A. E., Reeves, C. E., Oram, D. E., Mills, G., Bandy, B. J., Stewart, D., Coe, H., Williams, P., and Crosier, J.: Chemical composition observed over the mid-Atlantic and thedetection of pollution signatures far from source regions, J. Geophys. Res., 112, D10S39, doi:10.1029/2006JD007584, 2007.

Lewis, A. C., Evans, M. J., Hopkins, J. R., Punjabi, S., Read, K. A., Purvis, R. M., Andrews, S. J., Moller, S. J., Carpenter, L. J., Lee, J. D., Rickard, A. R., Palmer, P. I., and Parrington, M.: The influence of biomass burning on the global distribution of selected non-methane organic compounds, Atmos. Chem. Phys., 13, 851-867, doi:10.5194/acp-13-851-2013, 2013.

Lonbladd, L., Peterson, C., and Röngvaldsson, T.: Pattern recognition in high energy physics with artificial neural network - Jetnet 2.0., Comput. Phys. Comm., 70, 167-182, 1992.

Marlon, J. R., Bartlein, P. J., Carcaillet, C., Gavin, D. G., Harrison, S. P., Higuera, P. E., Joos, F., Power, M. J., and Prentice, I. C.: Climate and human influences on global biomass burning over the past two millennia, Nat. Geosci., 1, 69-702, 2008.

Mauzerall, D., Jacob, D. J., Fan, S.-M., Bradshaw, J., Gregory, G., Sachse, G., and Blake, D.: Origin of tropospheric ozone at remote high northern latitudes in summer, J. Geophys. Res., 101, 41754188, 1996.

Moussa, S. G., Amy Leithead, A., Li, S.-M., Chan, T. K, Wentzell, J. J. B., Stroud, C., Zhang, J., Lee, P., Lu, G., Brook, J. R., Hayden, K., Narayan, J., and Liggio, J.: Emissions of hydrogen cyanide fromon-road gasoline and diesel vehicles, Atmos. Environ., 131, 185-195, 2016.

Murphy, J. G., Oram, D. E., and Reeves, C. E.: Measurements of volatile organic compounds over West Africa, Atmos. Chem. Phys., 10, 5281-5294, doi:10.5194/acp-10-5281-2010, 2010.
Palmer, P. I., Parrington, M., Lee, J. D., Lewis, A. C., Rickard, A. R., Bernath, P. F., Duck, T. J., Waugh, D. L., Tarasick, D. W., Andrews, S., Aruffo, E., Bailey, L. J., Barrett, E., Bauguitte, S. J.-B., Curry, K. R., Di Carlo, P., Chisholm, L., Dan, L., Forster, G., Franklin, J. E., Gibson, M. D., Griffin, D., Helmig, D., Hopkins, J. R., Hopper, J. T., Jenkin, M. E., Kindred, D., Kliever, J., Le Breton, M., Matthiesen, S., Maurice, M., Moller, S., Moore, D. P., Oram, D. E., O’Shea, S. J., Owen, R. C., Pagniello, C. M. L. S., Pawson, S., Percival, C. J., Pierce, J. R., Punjabi, S., Purvis, R. M., Remedios, J. J., Rotermund, K. M., Sakamoto, K. M., da Silva, A. M., Strawbridge, K. B., Strong, K., Taylor, J., Trigwell, R., Tereszchuk, K. A., Walker, K. A., Weaver, D., Whaley, C., and Young, J. C.: Quantifying the impact of BOReal forest fires on Tropospheric oxidants over the Atlantic using Aircraft and Satellites (BORTAS) experiment: design, execution and science overview, Atmos. Chem. Phys., 13, 6239-6261, doi:10.5194/acp-13-6239-2013, 2013.

Parrington, M., Palmer, P. I., Henze, D. K., Tarasick, D. W., Hyer, E. J., Owen, R. C., Helmig, D., Clerbaux, C., Bowman, K. W., Deeter, M. N., Barratt, E. M., Coheur, P.-F., Hurtmans, D., Jiang, Z., George, M., and Worden, J. R.: The influence of boreal biomass burning emissions on the distribution of tropospheric ozone over North America and the North Atlantic during 2010, Atmos. Chem. Phys., 12, 2077-2098, doi:10.5194/acp-12-20772012, 2012.

Parrington, M., Palmer, P. I., Lewis, A. C., Lee, J. D., Rickard, A. R., Di Carlo, P., Taylor, J. W., Hopkins, J. R., Punjabi, S., Oram, D. E., Forster, G., Aruffo, E., Moller, S. J., Bauguitte, S. J.-B., Allan, J. D., Coe, H., and Leigh, R. J.: Ozone photochemistry in boreal biomass burning plumes, Atmos. Chem. Phys., 13, 73217341, doi:10.5194/acp-13-7321-2013, 2013.

Real, E., Law, K. S., Weinzierl, B., Fiebig, M., Petzold, A., Wild, O., Methven, J., Arnold, S., Stohl, A., Huntrieser, H., Roiger, A., Schlager, H., Stewart, D., Avery, M., Sachse, G., Browell, E., Ferrare, R., and Blake, D.: Processes influencing ozone levels in Alaskan forest fire plumes during long-range transport over the North Atlantic, J. Geophys. Res., 112, D10S41, doi:10.1029/2006JD007576, 2007.

Reid, J. S., Hyer, E. J., Prins, E. M., Westphal, D. L., Zhang, J., Wang, J., Christopher, S. A., Curtis, C. A., Schmidt, C. C., Eleuterio, D. P., Richardson, K. A., and Hoffman, J. P.: Global monitoring and forecasting of biomass burning smoke: Description of and lessons from the Fire Locating and Modeling of Burning Emissions (FLAMBE) program, IEEE J. Sel. Top. Appl., 2, 144-162, 2009.

Reidmiller, D. R., Jaffe, D. A., Fischer, E. V., and Finley, B.: Nitrogen oxides in the boundary layer and free troposphere at the Mt. Bachelor Observatory, Atmos. Chem. Phys., 10, 6043-6062, doi:10.5194/acp-10-6043-2010, 2010.

Rinsland, C. P., Dufour, G., Boone, C. D., Bernath, P. F., Chiou, L., Coheur, P.-F., Turquety, S., and Clerbaux, C.: Satellite boreal measurements over Alaska and Canada during June-July 2004: Simultaneous measurements of upper tropospheric CO, $\mathrm{C}_{2} \mathrm{H}_{6}, \mathrm{HCN}, \mathrm{CH}_{3} \mathrm{Cl}, \mathrm{CH}_{4}, \mathrm{C}_{2} \mathrm{H}_{2}, \mathrm{CH}_{3} \mathrm{OH}, \mathrm{HCOOH}, \mathrm{OCS}$, and SF6 mixing ratios, Global Biogeochem. Cy., 21, GB3008, doi:10.1029/2006GB002795, 2007.

Tereszchuk, K. A., González Abad, G., Clerbaux, C., Hurtmans, D., Coheur, P.-F., and Bernath, P. F.: ACE-FTS measurements of trace species in the characterization of biomass burning plumes, 
Atmos. Chem. Phys., 11, 12169-12179, doi:10.5194/acp-1112169-2011, 2011.

Vay, S. A., Choi, Y., Vadrevu, K. P., Blake, D. R., Tyler, S. C., Wisthaler, A., Hecobian, A., Kondo, Y., Diskin, G. S., Sachse, G.

W., Woo, J.-H., Weinheimer, A. J., Burkhart, J. F., Stohl, A., and Wennberg, P. O.: Patterns of $\mathrm{CO}_{2}$ and radiocarbon across high northern latitudes during International Polar Year 2008, J. Geophys. Res., 116, D14301, doi:10.1029/2011JD015643, 2011.

Val Martin, M., Honrath, R., Owen, R. C., Pfister, G., Fialho, P., and Barata, F.: Significant enhancements of nitrogen oxides, ozone and aerosol black carbon in the North Atlantic lower free troposphere resulting from North American boreal wildfires, J. Geophys. Res., 111, D23S60, doi:10.1029/2006JD007530, 2006.

Vemuri, V.: Artificial neural networks: theoretical concepts, ch. Artificial neural networks: an introduction, Los Alamitos, CA, USA, IEEE Computer Society Press, 1-12, 1988.
Wilson, K. L. and Birks, J. W.: Mechanism and Elimination of a Water Vapor Interference in the Measurement of Ozone by UV Absorbance, Environ. Sci. Techol., 40, 6361-6367,2006.

Wofsy, S. C., Sachse, G. W., Gregory, G. L., Blake, D. R., Bradshaw, J. D., Sandholm, S. T., Singh, H. B., Barrick, J. A., Harriss, R. C., Talbot, R. W., Shipham, M. A., Browell, E. V., Jacob, D. J., and Logan, J. A.: Atmospheric chemistry in the Arctic and subarctic: Influence of natural fires, industrial emissions, and stratospheric inputs, J. Geophys. Res., 97, 16731-16746, doi:10.1029/92JD00622, 1992.

Wotawa, G. and Trainer, M.: The influence of Canadian forest fires on pollutant concentrations in the United States, Science, 288, 324-328, 2000. 